\title{
ALMA MATER VILNENSIS. OKOLICZNOŚCI WSKRZESZENIA UNIWERSYTETU STEFANA BATOREGO W WILNIE
}

\author{
Anna SUPRUNIUK (Uniwersytet Mikołaja Kopernika, Toruń) \\ ORCID: 0000-0003-3519-3319
}

Carski ukaz z 1 maja 1832 roku zamykał ponad 250-letnią, nieomal ciągłą, działalność uczelni w Wilnie. Decyzja cara Mikołaja I likwidująca Cesarski Uniwersytet Wileński spowodowała, że zniknął on z przestrzeni miasta, a jego majątek zniszczono lub rozparcelowano. Wszelako nie zlikwidowała legendy Almae Matris Vilnensis, która pielęgnowana w pamięci mieszkańców Wielkiego Księstwa Litewskiego przez następne 87 lat, ułatwiła restytucję Uniwersytetu w 1919 roku. Nie bez racji Wiktor Sukiennicki, należący do pierwszego rocznika pierwszego „pokolenia” studentów wskrzeszonego w roku 1919 uniwersytetu, pisał po latach:

\begin{abstract}
Materialne skarby Wszechnicy zostały wówczas rozgrabione i z Wilna wywiezione, a pamięć o niej trzebiona, czy nawet wręcz sterylizowana. [...] Nazwiska profesorów wileńskich w większości wypadków były równie niecenzuralne jak i nazwiska ich najznakomitszych uczniów. [...] Legenda o dawnym Uniwersytecie Wileńskim i jego profesorach i uczniach powstała i przez prawie cały wiek przetrwała wśród ludu na życzenie lub wbrew najsurowszym zakazom ówczesnych władz. [...] Gdzieś w niedostępnym zaborcom „podziemiu” wśród ludu „prostego”, nie w oficjalnej prasie, książkach, czy wśród robiących świetne nieraz kariery inteligentów, powstała i utrzymała się legenda o Uniwersytecie Wileńskim i jego niezwykłych, „,nadzwyczajnych” uczniach i profesorach ${ }^{1}$.
\end{abstract}

Po zamknięciu w 1842 roku Akademii Medyko-Chirurgicznej i przeniesieniu do Petersburga Akademii Duchownej władzom carskim wydawało się, że uczelnia zniknie nie tylko z przestrzeni miasta, ale także z pamięci jego mieszkańców. Jednak owa legenda powodowała, że od połowy XIX do początków XX wieku podejmowano w Wil-

\footnotetext{
${ }^{1}$ W. Sukiennicki, Legenda i rzeczywistość: wspomnienia i uwagi o dwudziestu latach Uniwersytetu Stefana Batorego w Wilnie, Paryż 1967, s. 14, 122.
} 
nie próby jej odtworzenia. Już w połowie XIX wieku pierwsze dwie podjęli, niedługo po zamknięciu Uniwersytetu, marszałkowie szlachty wileńskiej i grodzieńskiej: Edward Mostowski i Kalikst Orzeszko. I obie próby zakończyły się odmową imperatora. Pojawiały się bowiem w czasie, gdy „kapitał” osobowy i materialny dawnego Uniwersytetu Wileńskiego wykorzystywany był do tworzenia innych uczelni w Rosji (np. Cesarskiego Uniwersytetu Kijowskiego św. Włodzimierza) ${ }^{2}$.

Wybuch i upadek powstania styczniowego, w którym szlachta i inteligencja dawnego Wielkiego Księstwa Litewskiego była zaangażowana szczególnie mocno, uniemożliwiły jakiekolwiek poważne starania i plany odbudowy uczelni w Wilnie na kolejne 40 lat. Mianowany 1 maja 1863 roku na nowego generał-gubernatora Kraju Północno-Zachodniego hrabia Michaił Mikołajewicz Murawjow otrzymał od cara Aleksandra II nieograniczone pełnomocnictwa i zadanie przywrócenia spokoju oraz ukarania wszystkich winnych za wybuch rewolty. Kolejni generał-gubernatorzy wileńscy wypełniali literalnie polecenia carów Aleksandra II i III, dążące do „zespolenia” tych obszarów z Imperium Rosyjskim oraz ich depolonizacji i rusyfikacji. Być może dlatego jedyny w tamtym czasie projekt utworzenia wileńskiej uczelni wyszedł w 1897 roku spod pióra członka Rady Miejskiej Wilna M. Władimirowa, a argumentacja odnosiła się do konieczności zamazania występków dawnego Uniwersytetu ${ }^{3}$.

Polskie inicjatywy założenia w Wilnie wyższej uczelni, mające realne szanse powodzenia, tak z racji możliwości finansowych, jak i osobowych, pojawiły się dopiero w początkach XX wieku. Na przełomie 1901 i 1902 roku starania w sprawie reaktywowania szkoły wyższej w Wilnie podjęło Wileńskie Towarzystwo Rolnicze. Projekt uczelni rolniczej przygotowany $\mathrm{w}$ gronie rady Towarzystwa zgłosili hrabia Antoni Tyszkiewicz i Hipolit Gieczewicz. Być może ośmieliła ich zgoda cesarska na restytucję Towarzystwa po wielu latach starań w końcu 1899 roku. Koncepcja zakładała uruchomienie w Wilnie wyższej szkoły o profilu rolniczym w rodzaju „politechniki z kilkoma wydziałami”. I tym razem władze carskie negatywnie zareagowały na tę inicjatywę, chociaż oficjalny wniosek o restytucję Uniwersytetu nigdy nie został przez Towarzystwo złożony. Był to okres rządów w Wilnie w latach 1897-1901 generał-gubernatora wileńskiego, kowieńskiego i grodzieńskiego Witalija Nikołajewicza Trockiego, dzięki którego staraniom powstało $\mathrm{w}$ mieście najpierw muzeum, a potem odsłonięto pomnik Michaiła Murawiowa. Trocki opowiadał się także za utrzymaniem wszystkich restrykcji nałożonych na polską szlachtę po powstaniu styczniowym, tępił wszelkie odstępstwa od tej polityki nie godząc się na założenie żadnych polskich towarzystw oświatowych lub naukowych ${ }^{4}$.

\footnotetext{
${ }^{2}$ Zob.: J. Kozłowska-Studnicka, Likwidacja Uniwersytetu Wileńskiego w świetle korespondencji urzędowej, [w:] Księga pamiątkowa, ku uczczeniu CCCL rocznicy założenia i X wskrzeszenia Uniwersytetu Wileńskiego, t. 1: Z dziejów dawnego Uniwersytetu, Wilno 1929, s. 406419. W momencie zamknięcia Uniwersytet Wileński był największą uczelnią w Cesarstwie, na której studiowało ponad 1300 osób (wg Daniela Beauvois ok. 2000).

${ }^{3}$ W. Wołkanowski, Michat Westawski: biografia prezydenta Wilna w latach 1905-1916, Opole 2015, s. 250-251. Tzw. Kraj Północno-Zachodni obejmował sześć guberni byłego Wielkiego Księstwa Litewskiego, tj. wileńską, grodzieńską, kowieńską, mińską, mohylewską i witebską, a od grudnia 1866 r. także suwalską i łomżyńską.

${ }^{4}$ H. Ilgiewicz, Societates Academicae Vilnenses: Towarzystwo Przyjaciół Nauk w Wilnie (1907-1939) i jego poprzednicy, Warszawa 2008, s. 23-24, opisuje także inne inicjatywy podejmowane wówczas nielegalnie przez polską inteligencję, w tym np. zakładanie tajnych bibliotek, kół samokształceniowych czy kursów dla nauczycieli, Tamże, s. 25-29. Zob. też: W. Wołkanowski, Michał Westawski: biografia prezydenta Wilna, s. 251.
} 
W tym samym czasie temat wskrzeszenia uczelni podjęły też władze municypalne. Niejako poszerzeniem projektu Towarzystwa było wydarzenie z 1903 roku, kiedy na zjeździe towarzyszącym Wystawie Rolniczej w Dyneburgu/Dźwińsku, któremu przewodniczył Stanisław Łopaciński, jako pierwszy punkt rozpatrywano kwestię utworzenia „wyższego zakładu naukowego dla Kraju Północno-Zachodniego”. Uczestnicy zjazdu zgodzili się na uniwersytet $\mathrm{z}$ obszernym wydziałem agronomicznym. I tym razem władze carskie negatywnie zareagowały na tę inicjatywę ${ }^{5}$.

Sprawa powołania uniwersytetu wróciła podczas posiedzeń Rady Miasta Wilna w końcu 1906 i ponownie w początkach 1908 roku. Pisał o tym Józef Ziemacki w artykule $O$ wznowieniu uniwersytetu $w$ Wilnie zamieszczonym w „Dzienniku Wileńskim” w końcu listopada 1918 roku:

[...] Przed laty kilkunastu sprawa utworzenia uniwersytetu szła żywo. Zezwolono na zjazd przedstawicieli większych miast tego kraju. [...] Zjechali się przedstawiciele zarządów miejskich Mohylewa, Witebska, Dyneburga, Grodna, Mińska i Kowna. Zebrało się około 100 osób. Utworzono komisję; prezydował ś. p. M. Węsławski. Akta tej komisji zawierają wiele starannie i źródłowo opracowanych memorjałów, które w danej chwili posiadają tylko historyczną wartość. Ostatecznym wynikiem było postanowienie ufundowania w Wilnie Akademii Rolniczej. Gubernator dał przychylną odezwę. Ministrowie obiecali swe poparcie. Ale to wszystko było ułuda i obłuda. Z góry bowiem w Petersburgu była sprawa przesądzona, że żadnej Akademji Rolniczej tu nie będzie ${ }^{6}$.

Powołana przez Michała Węsławskiego, ówczesnego prezydenta Wilna, komisja przygotowała dwa projekty uczelni: pierwszy, o profilu humanistycznym; drugi, szkoły na wzór politechniki. Pojawił się też trzeci, plan powołania wyższej uczelni z wydziałami: prawa, medycyny, fizyczno-matematycznym, rolniczym i filologicznym.

W Wilnie 4 maja 1908 roku zwołano zjazd w sprawie uczelni, na który przybyli delegaci rad miejskich, towarzystw rolniczych, banków i zakładów naukowych z sześciu guberni. W trakcie obrad wyłoniono podkomisję do opracowania projektu uczelni mieszanej, uniwersytetu z kilkoma wydziałami, w tym fakultetem rolniczym, który miał zlikwidować tarcia między poszczególnymi narodowościami. Komisja spotykała się regularnie do połowy 1909 roku, po czym plany przeleżały w kancelarii miasta kolejne dwa lata. Wydaje się, że szukano pretekstu, by przedstawić je carowi. W końcu 1911 roku na posiedzeniu Rady Miasta Wilna Mikołaj Soboliew zgłosił projekt wyższej uczelni, która miała powstać w rocznicę uczczenia trzechsetlecia panowania Romanowów w Rosji i otrzymać imię carskiej rodziny (Uniwersytet Cesarsko-Romanowski). Wówczas złożono też deklarację przekazania przez miasto na ten cel miliona rubli i 20 dziesięcin ziemi. Czy projekt trafił do Petersburga, nie wiemy. W końcu 1913 roku pojawił się kolejny, który modyfikował poprzednie. Ustalono, że należy zabiegać o „Uniwersytet Ludowy” z profilem rolniczym pod patronatem Romanowów; wybrano deputację złożoną z przedstawicieli wszystkich narodowości, która miała przedstawić carowi petycję w tej sprawie. W Ministerstwie Spraw Wewnętrznych złożono prośbę o posłuchanie u cara Mikołaja II. Gdy ten po kilku tygodniach na audiencję się nie

\footnotetext{
${ }^{5}$ W. Wołkanowski, Michał Węstawski: biografia prezydenta Wilna, s. 252 i n.; Z. Opacki, Reaktywowanie czy powstanie? Dyskusje wokót utworzenia Uniwersytetu Stefana Batorego w Wilnie w latach 1918-1919, Kwartalnik Historyczny 1998 nr 3, s. 50; A. Srebrakowski, Litwa i Litwini na Uniwersytecie Stefana Batorego, [w:] Stosunki polsko-litewskie wczoraj i dziś: historia, kultura, polityka, red. W. K. Roman, J. Marszałek-Kawa, Toruń 2009, s. 106-107.

${ }^{6}$ J. Ziemacki, $O$ wznowieniu Uniwersytetu $w$ Wilnie, cz. 1-2, Dziennik Wileński 1918 nr 270 (z 20 listopada), s. 2-3; nr 272, s. 2 (z 22 listopada). Początkowo myślano o założeniu w Wilnie kursów żeńskich, projekt ten popierał także prezydent M. Węsławski.
} 
zgodził, przygotowano nowy memoriał na wypadek zmiany decyzji. Wybuch wojny położył kres tym zamierzeniom? ${ }^{7}$.

Nadzieje na powołanie w Wilnie wyższej uczelni odżyły wkrótce po wybuchu pierwszej wojny światowej, kiedy zmieniła się sytuacja polityczna, a wojska rosyjskie opuściły miasto. Nie bez znaczenia był zapewne fakt powołania przez gen. Hansa $\mathrm{H}$. von Beselera w Warszawie polskiego uniwersytetu w miejsce opuszczonej przez Rosjan uczelni. Tuż przed zajęciem miasta przez władze niemieckie utworzono składający się z przedstawicieli różnych narodowości Komitet Obywatelski Wileńsko-Kowieński mający pełnić funkcję lokalnego rządu, którego statut zatwierdził jeszcze przed opuszczeniem Wilna ostatni gubernator rosyjski Piotr Władimirowicz Wierowkin ${ }^{8}$.

We wrześniu 1915 roku Wilno znalazło się pod okupacją niemiecką. Kilku przedstawicieli inteligencji wileńskiej na przełomie 1915 i 1916 roku przedstawiło kolejny projekt odbudowy Uniwersytetu, uruchomiło też wyższe kursy naukowe, zwane „uniwersytetem latającym". Władze niemieckie projekt uczelni odrzuciły, mimo że w lutym 1916 roku wydały zgode na druk „Dziennika Wileńskiego” wydawanego przez Jana Obsta. Wkrótce też zawiesiły kursy naukowe i działalność powstałego z inicjatywy Alfonsa Parczewskiego i Władysława Zahorskiego w październiku 1906 roku Wileńskiego Towarzystwa Przyjaciół Nauk, którego głównym celem była troska o rozwój nauki i literatury w języku polskim oraz badania: przyrodnicze, etnograficzne i statystyczne kraju' . Dla grupy osób skupionych wokół Towarzystwa, w tym m.in. Ludwika Abramowicza, Stanisława Kościałkowskiego, Ludwika Czarkowskiego, Czesława Jankowskiego, Lucjana Uziębło, Józefa Ziemackiego czy Stanisława Władyczki, idea odtworzenia wyższej uczelni w Wilnie była celem nadrzędnym. I jakkolwiek ich starania nie powiodły się, były potwierdzeniem, że wśród Wilnian wciąż żywa było pamięć i legenda Almae Matris Vilnensis oraz pragnienie jej odbudowy. Wspominano o tym

${ }^{7}$ Lietuvos Centrinis Valstybes Archyvas w Wilnie (dalej: LCVA), F. 175, ap. 1(I)A, b. 13, k. 45, Protokoły Komisji Organizacyjno-Rewindykacyjnej Uniwersytetu Wileńskiego, protokół z 21 maja 1919 r. W trakcie posiedzenia Komisji Wacław Gizbert-Studnicki przypomniał o inicjatywie sfer ziemiańskich z 1909 lub 1910 r. założenia wyższego zakładu naukowego w Wilnie i ofiarowania przez pana Ogińskiego kilku dziesięcin ziemi na Antokolu na potrzeby przyszłej uczelni. Zob. też: W. Wołkanowski, Michat Węstawski: biografia prezydenta Wilna, s. 250-258, szczegółowo opisał starania o wyższą uczelnię w Wilnie i udział w nich prezydenta M. Węsławskiego; J. Schiller, Universitas rossica: koncepcja rosyjskiego uniwersytetu 1863-1917, Warszawa 2008, s. 363, pisze, że w latach 1860-1914 Wilno pięciokrotnie prosiło kolejnych carów o uniwersytet, instytuty: technologiczny, rolniczy, politechniczny, akademię duchowną, i ofiarowało 500 tys. rubli.

${ }^{8}$ H. Ilgiewicz, Relacje polsko-litewskie $w$ przededniu odzyskania niepodległości $w$ świetle dzienników $i$ wspomnień działaczy wileńskich, Rocznik Stowarzyszenia Naukowców Polaków Litwy 2019 t. 19, s. 4-7, władze okupacyjne niemieckie początkowo uznały działalność Komitetu, by później ograniczyć jego funkcję tylko do działalności dobroczynnej, a w końcu 1916 r. go rozwiązać.

9 A. Wrzosek, Wskrzeszenie Uniwersytetu Wileńskiego w roku 1919, [w:] Ksiegga pamiatkowa, ku uczczeniu CCCL rocznicy założenia i $X$ wskrzeszenia Uniwersytetu Wileńskiego, t. 2: Dziesięciolecie 1919-1929, Wilno 1929, s. 2 i n., pisał, że w lutym 1916 r. w jednej z gazet krakowskich ukazał się artykuł $O$ Uniwersytet $w$ Wilnie, w którym zamieszczono wzmiankę o przedłożeniu w grudniu 1915 r. władzom niemieckim memoriału w sprawie wskrzeszenia uczelni w Wilnie; H. Ilgiewicz, Societates Academicae Vilnenses, s. 272 i n., opisała m.in. okoliczności powstania i działalność Wileńskiego Towarzystwa Przyjaciół Nauk; Taż, Wileńskie towarzystwa naukowe w latach pierwszej wojny światowej, Rocznik Stowarzyszenia Naukowców Polaków Litwy 2015 t. 15, s. 42-47. 
w początkach stycznia 1919 roku na pierwszym organizacyjnym posiedzeniu Komisji do uruchomienia Uniwersytetu Wileńskiego, na którym podkreślono, że

[...] myśl wznowienia działalności Uniwersytetu Wileńskiego należała i należy do spraw najżywiej ogół inteligencji polskiej w Wilnie obchodzących i że przy każdej możliwości czyniono po temu wysiłki, a mianowicie: po ustąpieniu z Wilna w r. 1915 władz rosyjskich, stworzone zostały Wyższe Kursy Naukowe, które rozwijały się bardzo pomyślnie, lecz zostały zawieszone przez niemieckie władze okupacyjne ${ }^{10}$.

Wypada zauważyć, że równolegle z polskimi, zabiegi o restytucję uniwersytetu podjęły także władze odrodzonego państwa litewskiego. Powstałe w Wilnie w 1915 roku Litewskie Towarzystwo Pomocy Ofiarom Wojny, zwane Komitetem Litewskim, na którego czele stanął Antanas Smetona, mając przychylność władz niemieckich, prowadziło działalność charytatywną i polityczną na tym terytorium i zagranicą. We wrześniu 1917 roku, za zgodą niemieckich władz okupacyjnych, powołano w Wilnie Litewską Radę Państwową (Lietuvos Taryba) na czele z Antanasem Smetoną, która 16 lutego 1918 roku ogłosiła „Akt niepodległości Litwy”. W listopadzie tego roku Taryba otrzymała od okupujących miasto Niemców zgodę na powołanie rządu. 11 listopada Augustinas Voldemaras został zaprzysiężony na premiera i uformował pierwszy rząd litewski, który ze zmianami działał w Wilnie do 1 stycznia 1919 roku. Inicjatywę odrodzenia Uniwersytetu w Wilnie podjęło Litewskie Towarzystwo Naukowe, które w październiku 1918 roku wyłoniło komisję do opracowania projektu statutu nowej uczelni, przygotowanego m.in. przez Jurgisa Aleknę, Mykolasa Biržiškę, Aleksandrasa Stulginskisa. Już 5 grudnia 1918 roku Tymczasowy Rząd Litwy przyjął statut, którego punkt pierwszy głosił, że Uniwersytet Wileński, „wskrzeszony z dniem 1 stycznia 1919 r., jest spadkobiercą instytucji nauki i nauczania Wileńskiego Uniwersytetu, zamkniętego w 1832 r.”. Statut zakładał, że uczelnia miała być państwowym uniwersytetem litewskim, na którym zajęcia prowadzono by także w języku polskim i rosyjskim. Na litewskiej uczelni planowano cztery fakultety: teologii, nauk społecznych, medycyny, nauk przyrodniczych i matematyki. Początkowo działalność miały rozpocząć tylko dwa wydziały: teologii i nauk społecznych. Daleko więc różna miała to być uczelnia od XIX-wiecznego Uniwersytetu Wileńskiego. Zmieniająca się sytuacja polityczna uniemożliwiła urzeczywistnienie tych zamierzeń. Po 1 stycznia 1919 roku rząd litewski wraz z Tarybą przeniósł się do Kowna, gdzie - po dwóch latach wojen i po ustaleniu granic Litwy - powołał Uniwersytet Litewski w Kownie, w kształcie przewidzianym w statucie $\mathrm{z}$ grudnia $1918 \mathrm{roku}^{11}$.

${ }^{10}$ LCVA, F. 175, ap. 1(I)A, b. 13, k. 2, Protokoły Komisji Organizacyjno-Rewindykacyjnej Uniwersytetu Wileńskiego, Protokół Nr I organizacyjnego posiedzenia Komisji do uruchomienia Uniwersytetu Wileńskiego, Wilno, 4 stycznia $1919 \mathrm{r}$.

${ }^{11}$ S. Jegelevičius, Pierwsze próby wskrzeszenia Uniwersytetu Wileńskiego i powstanie Uniwersytetu Stefana Batorego, [w:] Z dziejów Almae Matris Vilnensis: księga pamiatkowa ku czci 400-lecia zatożenia i 75-lecia wskrzeszenia Uniwersytetu Wileńskiego, red. L. Piechnik, K. Puchowski, Kraków 1996, s. 243-244 (polemika: W. Dziewulski, Prawda o wskrzeszeniu Wileńskiej Wszechnicy w 1919 roku, [w:] Tamże, s. 282-283); Z. Opacki, Reaktywowanie czy powstanie? Dyskusje wokót utworzenia Uniwersytetu Stefana Batorego, s. 52; D. Zamojska, „Ta ludność życzy mieć uniwersytet..." - walka o utworzenie Uniwersytetu Stefana Batorego w Wilnie, Kwartalnik Historii Nauki i Techniki 2006 z. 2, s. 8-9. Zob. też: Stepono Batoro universitetas: perimti ir isigyti turtai (1919-1939), [w:] Alma Mater Vilnensis: Vilniaus universiteto turtai istorijos skersvejuose (XVI-XXI amžiai), [redaktorių kolegija], Vilnius 2016, s. 385-386. Litwini od roku 1905 dążyli do stworzenia systemu oświaty, na czele którego miał stanąć uniwersytet 
Nie ulega wątpliwości, że skuteczność działań inteligencji litewskiej spowodowała przyśpieszenie poczynań strony polskiej. Idea reaktywowania Uniwersytetu w Wilnie, która powróciła pod koniec 1918 roku, stanowiła dla członków Towarzystwa Naukowego asumpt do wskrzeszenia tej uczelni w roku następnym. Tymczasem jednak artykułowano zamiary. W listopadzie 1918 roku w „Dzienniku Wileńskim” ukazał się cytowany wyżej artykuł Józefa Ziemackiego $O$ wznowieniu uniwersytetu $w$ Wilnie, w którym autor podkreślił potrzebę i możność szybkiego wskrzeszenia uczelni w Wilnie z wydziałami: teologicznym, prawnym, matematyczno-fizycznym, historyczno-filologicznym, lekarskim i agronomicznym:

[...] Teraz nikt nie może przeszkodzić sprawie odbudowania uniwersytetu polskiego w Wilnie. Uniwersytet upomni się o swe gmachy, o swe fundacje. Któż będzie mógł tego mu nie dać? A miasto, gdy zarząd grodem naszym przejdzie w ręce prawnych jego gospodarzy, nie poskąpi mu ziemi i gmachów potrzebnych, gdyby w starych murach uniwersyteckich było mu za ciasno. [...] Otóż teraz jest moment w którym społeczeństwo polskie w Wilnie powinno ująć w swe dłonie sprawę odbudowania uniwersytetu. Nie trzeba ku temu krociowych sum. Niepotrzeba będzie opierać byt uniwersytetu, na tym czy owym samoopodatkowaniu się. Zapoczątkować trzeba w najskromniejszych rozmiarach, z jak najmniejszym nakładem. Po wojnie znajdą się środki najmniej przewidziane, najmniej spodziewane i one byt uniwersytetowi zapewnią. Zresztą uniwersytet wileński miał wielkie dotacje, miał olbrzymie muzea, wielką bibljotekę ${ }^{12}$.

Do idei restytucji polskiego uniwersytetu powrócono niemal równocześnie w Warszawie i Wilnie. Z inicjatywy działającej od 1917 roku przy Radzie Regencyjnej w Warszawie Komisji Litewskiej 13 grudnia 1918 roku została zwołana konferencja pod przewodnictwem ks. Antoniego Szlagowskiego, w trakcie której, po wysłuchaniu referatu Stanisława Władyczki „W sprawie wskrzeszenia Uniwersytetu Polskiego w Wilnie", jednogłośnie przyjęto uchwałę w sprawie wskrzeszenia Uniwersytetu Wileńskiego „nie później niż w jesieni r. 1919” oraz powołano Komitet Warszawski Odrodzenia Wszechnicy Polskiej w Wilnie z 12 członkami oraz Alfonsem Parczewskim, jako prezesem, i sekretarzem $\mathrm{S}$. Władyczką ${ }^{13}$.

Działający w Wilnie od 1916 roku Komitet Polski 28 grudnia 1918 roku przyjął odezwę autorstwa Stanisława Kościałkowskiego o powołaniu do życia zamkniętego w 1832 roku uniwersytetu, którego otwarcie, z czterema wydziałami, miało nastąpić nie później niż na jesieni 1919 roku, tj. z początkiem roku akademickiego 1919/1920:

[...] Uruchomione mają być cztery wydziały: teologiczny, prawa i administracyj, lekarski, filozoficzny w zakresie dwu sekcyj: matematyczno-przyrodniczej i humanistycznej — oraz pododdziały: agronomiczny, weterynaryjny i farmaceutyczny. Uniwersytet ma służyć nauce i kulturze ogólnoludzkiej pojętej jak najszerzej — zgodnie z wielkiemi

narodowy litewski. W czerwcu 1930 r., w rocznicę 500-lecia śmierci wielkiego księcia litewskiego Witolda, uroczyście zmieniono nazwę tej uczelni na Uniwersytet im. Witolda Wielkiego.

12 J. Ziemacki, O wznowieniu Uniwersytetu $w$ Wilnie, cz. 1-2, Dziennik Wileński 1918 nr 270 (z 20 listopada), s. 2-3; nr 272, s. 2 (z 22 listopada).

${ }^{13}$ LCVA, F. 175, ap. 1(I)A, b. 14, k. 4-5, Protokół posiedzenia Konferencji, zwołanej przez Komisję Litewską w Warszawie w sprawie wskrzeszenia Uniwersytetu Wileńskiego. Działo się dnia 13 grudnia roku 1918; LCVA, F. 175, ap. 2(VI)B, b. 2, k. 49-50, Rękopisy Wydziału Prawa i Nauk Społecznych USB 1929/30 (A. Parczewski, Przyczynek do wspomnienia o wskrzeszeniu Uniwersytetu w Wilnie w roku 1919, Wilno, 5 lipca 1929 r.); A. Wrzosek, Wskrzeszenie Uniwersytetu Wileńskiego, s. 4-5 - tam w całości opublikowano protokół konferencji Komisji Litewskiej z 13 grudnia $1918 \mathrm{r}$. 
tradycyami swojemi — i uwzględniać w sposób możliwie najlepszy potrzeby kulturalne

wszystkich mieszkańców Litwy i wszystkich narodowości kraj zamieszkujących"14.

Na marginesie warto dodać, że Stanisław Kościałkowski, wybitny historyk, był też autorem opracowania Uwagi nad zadaniami Komisji oraz trzech jej dotychczasowych Sekcji (podkomisji): finansowo-rewindykacyjnej, gospodarczej i programowo-naukowej, w którym postulował m.in. utworzenie katedr lituanistycznych z językiem wykładowym litewskim. Nie wykluczał również, co było dla wielu ówczesnych polskich działaczy trudne do zaakceptowania, powstania w Wilnie drugiego, samodzielnego uniwersytetu litewskiego, jak i udzielenia mu pomocy kadrowej ${ }^{15}$.

Wychodząc niejako naprzeciw działaniom obu inicjatyw profesorskich, Komitet Edukacyjny, upełnomocniony w Wilnie przez Komitet Polski, działający pod przewodnictwem Witolda Węsławskiego, na posiedzeniu 4 stycznia 1919 roku powołał do prowadzenia spraw naukowych tymczasowy Senat Akademicki na czele z rektorem Józefem Ziemackim. W skład Senatu Komitet Edukacyjny polecił powołać jako dziekanów planowanych wydziałów: Stanisława Ptaszyckiego (filozoficznego), Alfonsa Parczewskiego (prawnego), Stanisława Władyczkę (lekarskiego) oraz członków Kazimierza Noiszewskiego, Władysława Zawadzkiego i Stanisława Kościałkowskiego. Z 20 stycznia 1919 roku pochodziło pismo prezesa Komitetu Edukacyjnego W. Węsławskiego do J. Ziemackiego, w którym ,[...] proponuje Panu stanowisko t. cz. Rektora Uniwersytetu Wileńskiego dla podjęcia akcji w celu uruchomienia Uniwersytetu przy współudziale t. cz. Senatu Akademickiego"16.

Prócz tego na posiedzeniu 4 stycznia zapowiedziano powstanie „dla celów organizacyjnych i rewindykacyjnych" Komisji Organizacyjno-Rewindykacyjnej, która miała zająć się pracami przygotowawczymi zmierzającymi do uruchomienia Uniwersytetu Wileńskiego. Jej skład stanowili działacze społeczni i oświatowi z Wileńszczyzny, w tym m.in. Witold Węsławski, Władysław Zahorski, Konrad Niedziałkowski, Jan Piłsudski, Józef Wierzyński, Ludwik Czarkowski, Tadeusz Dembowski, Stanisław Cywiński, ks. Leon Puciata, książę Eustachy Sapieha, Emma Dmochowska, Zofia Paszkowska, Emilia Węsławska. Na drugim posiedzeniu Komisji OrganizacyjnoRewindykacyjnej, które odbyło się 6 stycznia pod przewodnictwem rektora J. Ziemackiego, uchwalono, że będzie on prezesem Komisji, co miało zapewnić koordynację

${ }^{14}$ LCVA, F. 175, ap. 1(I)A, b. 14, k. 6-7v, Odezwa Komitetu Polskiego w Wilnie, Wilno dnia 30 grudnia 1918 r. Zob. też: S. Władyczko, Pierwszy okres prac organizacyjnych nad odbudowa Uniwersytetu Wileńskiego (13.XII.1918-11.X.1919). Sprawozdanie Komitetu Wykonawczego Odbudowy Uniwersytetu Wileńskiego, [w:] Księga Pamiątkowa ku uczczeniu CCCL rocznicy założenia i X wskrzeszenia Uniwersytetu Wileńskiego, t. 2: Dziesięciolecie 1919-1929, Wilno 1929, s. 34-36.

${ }^{15}$ LCVA, F. 175, ap. 1(I)A, b. 13, k. 16v-17, 25-30, Protokół czwartego posiedzenia Komisji Organizacyjno-Rewindykacyjnej Uniwersytetu Wileńskiego z dnia 27 kwietnia r. 1919 w mieszkaniu d-ra Zahorskiego.

${ }^{16}$ LCVA, F. 175, ap. 1(I)A, b. 14, k. 11-11v, Wyciąg z protokołu posiedzenia Komitetu Edukacyjnego w Wilnie dn. 4 stycznia 1919 r. pod przewodnictwem prezesa Komitetu Edukacyjnego p. Dr-a Witolda Węsławskiego przy sekretarzu p. Wierzyńskim; LCVA, F. 175, ap. 1(I)A, b. 13, k. 2-2v, k. 6, Protokoły Komisji Organizacyjno-Rewindykacyjnej Uniw[ersytetu] Wil[eńskiego] (odpisy), zob.: protokół nr 1 i protokół nr 2; LCVA, F. 175, ap. 1(I)A, b. 1, k. 1a-4, Odpisy listów rektora J. Ziemackiego do A. Parczewskiego, W. Władyczki, Stanisława Ptaszyckiego, K. Noiszewskiego, W. Zawadzkiego i S. Kościałkowskiego, Wilno 10 stycznia 1919 r.; LCVA, F. 175, ap. 1(I)A, b. 16, k. 4, odpis pisma z 20 I [19]19 prezesa Komitetu Edukacyjnego. 
prac obu tych ciał, powołano także Władysława Zahorskiego na przewodniczącego podkomisji rewindykacyjnej.

W początkach stycznia 1919 roku Wilno ponownie stało się teatrem wojny. Po wycofaniu się wojsk niemieckich miasto zajęły oddziały Robotniczo-Chłopskiej Armii Czerwonej. Pod bolszewickim protektoratem do 27 lutego 1919 roku w Wilnie zaistniała Litewska Republika Rad, potem Litewsko-Białoruska Republika Rad z przewodniczącym Rady Komisarzy Ludowych Vincasem Mickievičiusem-Kapsukasem na czele. Władze tej republiki również podjęły ideę utworzenia uniwersytetu i 13 marca opublikowały „Dekret Rady Komisarzy Ludowych Litwy i Białorusi o utworzeniu w Wilnie Powszechnego Uniwersytetu Pracy”, który miał rozpocząć działalność wiosną tego roku. Dla urzeczywistnienia tej koncepcji została powołana Komisja Wykonawcza złożona z trzech komisarzy: Vaclovasa Biržiški, Stefana Heltmana i Stanisława Bobińskiego, którzy zwrócili się do rektora Ziemackiego z prośbą o przedstawienie projektu wznowienia uczelni wraz z listami kandydatów proponowanych na katedry ${ }^{17}$.

Działania wojenne i zajęcie miasta przez wojska bolszewickie spowodowały spowolnienie prac podjętych przez inteligencję polską nad wskrzeszeniem uczelni w Wilnie. Mimo niesprzyjającej sytuacji politycznej w gronie zaufanych osób nadal działała Komisja Organizacyjno-Rewindykacyjna, która gromadziła informacje o nieruchomościach dawnego Uniwersytetu, opracowywała projekty statutu nowej uczelni, poszukiwała odpowiednich funduszy i kadry do obsadzenia katedr przyszłej uczelni. Mimo wojny 12 marca odbyło się posiedzenie Tymczasowego Senatu Akademickiego, w trakcie którego dyskutowano nad nazwami katedr i ich obsadą na Wydziale Lekarskim, uchwalono także, by zwrócić się do dziekanów planowanych fakultetów w sprawie ich organizacji oraz obsady katedr ${ }^{18} .19$ marca 1919 roku do Warszawy wyjechał, uprawomocniony przez rektora Ziemackiego, Stanisław Władyczko „,...] do przedsiębrania akcji we wszelkich sprawach, mających na celu uruchomienie Uniwersytetu Wileńskiego". Tam, łącznie z członkami Komitetu Warszawskiego, wydano odezwę do społeczeństwa polskiego w sprawie restytucji Uniwersytetu Wileńskiego. W czasie tego pobytu Władyczko wraz z prof. Władysławem Zawadzkim spotkał się także z dyrektorem Departamentu dla Spraw Polskich Ziem Wschodnich Ludwikiem Kolankowskim oraz Szefem Departamentu Nauki i Szkół Wyższych w Ministerstwie WRiOP Adamem Wrzoskiem, którym przedstawił projekty i plan prac Tymczasowego Senatu Akademickiego oraz Komisji Organizacyjnej. Kolankowski mianował wówczas Władyczkę referentem spraw Uniwersytetu Wileńskiego w Zarządzie Ziem Wschodnich ${ }^{19}$.

${ }^{17}$ LCVA, F. 175, ap. 1(I)A, b. 14, k. 13-14v, dokument z przebiegu pertraktacji między Komisją Wykonawczą a prof. Ziemackim w sprawie utworzenia w Wilnie Powszechnego Uniwersytetu Pracy, 13 III [19]19 r. Republika formalnie obejmowała obszar obecnej Litwy, Białorusi i część Polski (Podlasie i Suwalszczyzna), faktycznie jej władza nie sięgała Podlasia i zachodniej części Litwy. Zlikwidowana została przez polską ofensywę w sierpniu 1919 r., a formalnie zniesiona 1 września przez jej rząd, który wycofał się do Smoleńska. Zob. też: A. Srebrakowski, Uniwersytet Stefana Batorego w Wilnie 1919-1939, [w:] Wroctaw na litewskie millenium. Materiały z uroczystej konferencji z okazji 1000-lecia udokumentowania nazwy Litwa, pod red. A. Srebrakowskiego i G. Straucholda, Wrocław 2010, s. 85-86.

${ }^{18}$ LCVA, F. 175, ap. 1(I)A, b. 14, k. 12-12v, Posiedzenie Senatu Akademickiego Uniwersytetu Wileńskiego w dn. 12 marca 1919 r.; LCVA, F. 175, ap. 1(I)A, b. 1, k. 8b-8c, Odpis listu Rektora Ziemackiego do Naczelnika Państwa z 27.IV [19]19 r.

${ }^{19}$ Zob.: LCVA, F. 175, ap. 1(I)A, b. 13, k. 42, relacja Władyczki z przebiegu wizyty w Warszawie przedstawiona na siódmym posiedzeniu Komisji Organizacyjno-rewindykacyjnej 21 maja 1919 r. Zob. też: S. Władyczko, Pierwszy okres prac organizacyjnych, s. 37, opisał działalność 
Ofensywa wojsk polskich rozpoczęła się 16 kwietnia 1919 roku. W jej wyniku 19 kwietnia Wilno zostało przejęte przez Polaków. Komisja Organizacyjno-Rewindykacyjna wznowiła obrady 25 kwietnia. Jeszcze tego dnia Władyczko otrzymał list od dyrektora Departamentu do spraw Polskich Ziem Wschodnich L. Kolankowskiego, w którym ten ostatni prosił, w imieniu Naczelnika Państwa, by „t.cz. Senat Akademicki w dalszym ciągu prowadził pracę nad uruchomieniem i organizacją Uniwersytetu Wileńskiego. Prace swe zechcą Panowie prowadzić w porozumieniu z Ministerjum W.R.iO.P. w Warszawie" ${ }^{20}$. Dwa dni później, 27 kwietnia, tymczasowy rektor Ziemacki mógł osobiście, podczas dwugodzinnej audiencji, złożyć przybyłemu do Wilna Naczelnemu Wodzowi Józefowi Piłsudskiemu relację z postępów działań Komitetu, przedstawić plan prac nad wskrzeszeniem uczelni, jej potrzeby oraz prosić o pomoc finansową i opiekę. Jeszcze tego samego dnia o godzinie 6 wieczorem w mieszkaniu W. Zahorskiego odbyło się posiedzenie Komisji Organizacyjno-Rewindykacyjnej, w trakcie której Ziemacki zdał relację z posłuchania u Naczelnego Wodza ${ }^{21}$. Ponieważ Wilno nie leżało $\mathrm{w}$ granicach odrodzonego państwa polskiego i podlegało administracji Generalnego Komisarza Cywilnego przy Zarządzie Cywilnym Ziem Wschodnich, Komisja została podporządkowana tej administracji.

Szczegółowy przebieg jej prac zmierzających do wskrzeszenia uczelni w Wilnie można odtworzyć na podstawie:

- relacji Adama Wrzoska, ówczesnego Szefa Sekcji Nauki i Szkół Wyższych w Ministerstwie Wyznań Religijnych i Oświecenia Publicznego (MWRiOP), opartej na protokołach z posiedzeń działającej w Wilnie Komisji Organizacyjno-Rewindykacyjnej oraz jego wspomnieniach ${ }^{22}$,

- $\quad$ wspomnień pierwszego rektora USB Michała M. Siedleckiego ${ }^{23}$,

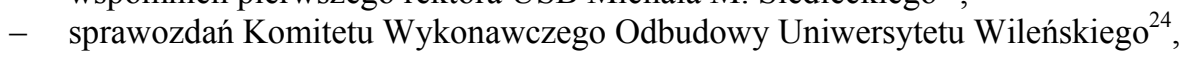

- $\quad$ wspomnień Ludwika Kolankowskiego, który od 7 maja do 30 sierpnia 1919 roku był pełnomocnikiem Naczelnego Wodza do spraw odbudowy Uniwersytetu w Wilnie ${ }^{25}$,

Komisji i Tymczasowego Senatu; D. Zamojska, Akademicy i urzędnicy: kształtowanie ustroju państwowych szkól wyższych w Polsce 1915-1920, Warszawa 2009, s. 81.

${ }^{20}$ LCVA, F. 175, ap. 1(I)A, b. 1, k. 13, list S. Władyczki do J. Ziemackiego z 25 IV [19]19. W liście datowanym 23 kwietnia Władyczko przynaglał Ziemackiego do spotkania z Naczelnikiem Państwa w sprawie Uniwersytetu, tamże, k. 11; LCVA, F. 175, ap. 1(I)A, b. 16, k. 7, pismo od Dyrektora Departamentu L. Kolankowskiego do t.cz. Rektora Uniwersytetu Wileńskiego, 25 kwietnia 1919 r.

${ }^{21}$ LCVA, F. 175, ap. 1(I)A, b. 1, k. 8-8c, odpis listu rektora Ziemackiego do Naczelnika Państwa z 27.IV [19]19 r.; LCVA, F. 175, ap. 1(I)A, b. 13, Protokoły Komisji Rewizyjno-Organizacyjnej Uniw[ersytetu] Wil[eńskiego], k. 11-12 (protokół trzeciego posiedzenia z 25 kwietnia 1919 r.), k. 1617 (protokół czwartego posiedzenia z 27 kwietnia 1919 r.), k. 25-30 (opracowanie S. Kościałkowskiego). Józef Piłsudski na prace organizacyjne Komisji wyasygnował 30 tys. marek.

${ }^{22}$ A. Wrzosek, Wskrzeszenie Uniwersytetu Wileńskiego, s. 1-32.

${ }^{23}$ M. Siedlecki, Wspomnienia z pierwszych dwu lat organizacji Uniwersytetu Wileńskiego, [w:] Ksiega Pamiatkowa ku uczczeniu CCCL rocznicy zatożenia $i$ X wskrzeszenia Uniwersytetu Wileńskiego, t. 2: Dziesięciolecie 1919-1929, Wilno 1929, s. 59-114.

${ }^{24}$ LCVA, F. 175, ap. 1(I)A, b. 12a, Protokoły Komitetu Wykonawczego Odbudowy Uniwersytetu Wileńskiego (oryginały); S. Władyczko, Pierwszy okres prac organizacyjnych, s. 33-58. Od 27 maja do 13 września 1919 r. Komitet Wykonawczy działający pod przewodnictwem tymczasowego rektora J. Ziemackiego odbył 41 posiedzeń. 17 grudnia 1919 r. na wniosek rektora USB Michała Siedleckiego odbyło się ostatnie posiedzenie tego Komitetu (bez udziału L. Kolankowskiego).

${ }^{25}$ L. Kolankowski, Zapiski pamiętnikarskie, do druku przygotowała, wstępem i przypisami opatrzyła S. Grochowina, Toruń 2012, s. 109-147 [Udział we wskrzeszeniu Uniwersytetu Wileńskiego]. Misja Kolankowskiego zakończyła się 30 sierpnia 1919 r. 
- źródeł archiwalnych z Archiwum Uniwersytetu Stefana Batorego, które obecnie jest przechowywane w Litewskim Centralnym Archiwum Państwowym w Wilnie (Fond 175, ap. 1(I)A, b. 1-18).

Przy czym relacje A. Wrzoska, Komitetu Wykonawczego oraz wspomnienia M. Siedleckiego zostały opublikowane w drugim tomie Księgi Pamiatkowej ku uczczeniu CCCL rocznicy założenia $i X$ wskrzeszenia Uniwersytetu Wileńskiego wydanej w 1929 roku.

W dyskusji o koncepcjach Uniwersytetu w Wilnie pominięto najważniejszą, która wcześniej nie została wyartykułowana. 22 kwietnia, wkrótce po przybyciu do Wilna, Naczelnik Państwa wydał, w języku polskim i litewskim, odezwę Do mieszkańców byłego W[ielkiego] Księstwa Litewskiego, w której odwoływał się do potomków Rzeczypospolitej Obojga Narodów o wspólne działanie w odbudowie niepodległości, wszelako nie podejmując kwestii przynależności państwowej tych ziem. Spotkał się też z przedstawicielami władz Wilna i przedstawił im swoją wizję miasta i uczelni, które miały stać się centrum kultury polskiej. Nie ulega wątpliwości, że odbudowa uniwersytetu leżała w projektach federacyjnych Józefa Piłsudskiego, który chciał przekonać inne narodowości mieszkające w Wilnie do powstającego państwa polskiego. Jej realizację powierzył Ludwikowi Kolankowskiemu, byłemu dyrektorowi Departamentu Kresów Wschodnich (Litewsko-Białoruskiego) i Komisarzowi Cywilnemu przy Zarządzie Wojskowym Kresów Wschodnich, którego 7 maja 1919 roku powołał na stanowisko pełnomocnika Naczelnego Wodza do spraw odbudowy Uniwersytetu Wileńskiego, przekazując mu jednocześnie dokumentację tej uczelni ${ }^{26}$. Dzięki wydanym drukiem w roku 2012 Zapiskom pamiętnikarskim Kolankowskiego znamy nie tylko kulisy tego spotkania, ale także szczegóły jego udziału w restytucji Uniwersytetu Stefana Batorego.

Tak oto Kolankowski opisał w Zapiskach swą rozmowę z Piłsudskim:

Ot ma Pan z Wilna Kaziuka. Dali mi go tam, a ja go daję Panu. Spóźniony, ale wileński

Kaziuk. Na moje nieme pytanie, co to może być, dodał: „Umyślili sobie w Wilnie mieć tam uniwersytet. Mówiliśmy o tym — jak Pan już wie - długo, a tu są akty, co mi dali. Powiedziałem im, że to przekażę Panu". Na moją uwagę, że gdy jutro przekażę urząd panu Osmołowskiemu, do niego więc jako do Generalnego Komisarza będzie to należało, odparł Piłsudski: „Nie znają się na tym. Rozlezie się to, a Pan mi to zrobi”. „Rozkaz" — odrzekłem krótko $[\ldots]^{27}$.

W akcie nominacyjnym Naczelny Wódz zlecił Kolankowskiemu ,[...] zadanie opracowania łącznie $\mathrm{z}$ ciałem naukowym i miejscowymi instytucjami naukowymi statutów Wszechnicy oraz utworzenie dla tejże instytucji pomocniczych".

Upełnomocniony przez Piłsudskiego, Kolankowski inicjował i koordynował prace organizacyjne oraz we współpracy z Ministerstwem Wyznań Religijnych i Oświecenia Publicznego (MWRiOP) przygotował projekt doboru personelu naukowego. Wszelkie kwestie dotyczące zagadnień administracyjno-gospodarczych ustalał z Komisarzem Generalnym Zarządu Cywilnego Ziem Wschodnich Jerzym Osmołowskim ${ }^{28}$.

${ }^{26}$ Rolę L. Kolankowskiego w Departamencie Litewsko-Białoruskim MSZ i Komisariacie Cywilnym szczegółowo omówiła J. Gierowska-Kałłaur, Między polityka a nauka. Ludwik Kolankowski w pierwszym pótroczu 1919 roku, [w:] Ludwik Kolankowski: dzieło i życie: indywidualny przypadek historiograficzny, red. P. Oliński, W. Piasek, Toruń 2017, s. 23-40; Taż, Zarząd Cywilny Ziem Wschodnich (19 lutego 1919-9 września 1920), Warszawa 2003, s. 66-69, 71-72, 74, 111-112 i n.

${ }^{27}$ L. Kolankowski, Zapiski pamiętnikarskie, s. 119-120.

${ }^{28}$ D. Zamojska, ,,Ta ludność życzy mieć uniwersytet...,", s. 12; Taż, Akademicy i urzędnicy, s. 84; P. Żukowski, Uniwersytety we Lwowie, Krakowie i Wilnie na naukowej drodze Ludwika 
Zapał Kolankowskiego i wsparcie Piłsudskiego umożliwiły szybkie tempo prac odbudowy uczelni w Wilnie. 27 maja Pełnomocnik powołał Komitet Wykonawczy Odbudowy Uniwersytetu Wileńskiego pod przewodnictwem tymczasowego rektora J. Ziemackiego, w skład którego weszli przedstawiciele inteligencji wileńskiej, w tym m.in: Stanisław Władyczko, Ludwik Wasilewski, Stanisław Kościałkowski, Zygmunt Nagrodzki, Wacław Gizbert-Studnicki, Józef Wierzyński, Michał Brensztejn, Ludwik Czarkowski, Michał Minkiewicz, Walenty Parczewski, Ferdynand Ruszczyc, Witold Staniewicz, Witold Sławiński, Jan Obst, hrabia Antoni Tyszkiewicz, Władysław Zahorski. Komitet w porozumieniu z tymczasowym Senatem Akademickim miał rozpocząć niezbędne przygotowania do inauguracji roku akademickiego Wszechnicy Wileńskiej już w październiku 1919 roku oraz zaktywizować miejscowe społeczeństwo do pomocy w pracach przy organizacji uczelni, pozyskaniu budynków, mebli, opału czy zdobyciu odpowiednich funduszy itp. ${ }^{29}$. W końcu kwietnia do prac nad restytucją uczelni włączyło się również Ministerstwo WRiOP w osobie Adama Wrzoska, który objął kontrolę nad tworzącą się uczelnią, powstającą w mieście o nieustalonej wówczas co bardzo ważne - sytuacji prawnej.

Jak słusznie zauważyła Dorota Zamojska, od maja do 28 sierpnia 1919 roku odbudową uczelni w Wilnie zajmowało się kilka instytucji i osób, które między sobą toczyły spory kompetencyjne i koncepcyjne, co powodowało „wielowładztwo” prowadzące do opóźnienia prac organizacyjnych ${ }^{30}$.

Uruchomienie wyższej uczelni w tak szybkim tempie było nie tylko niezwykle trudnym przedsięwzięciem logistycznym, ale przede wszystkim finansowym. Wilno było miastem zrujnowanym wojną i biednym, o czym pisali we wspomnieniach niektórzy z profesorów, którzy w październiku 1919 roku podjęli pracę na tamtejszej uczelni. Najlepiej oddaje to zapis z dziennika Józefa Kallenbacha, dziekana Wydziału Humanistycznego, który po przyjeździe do Wilna zapisał: ,[...] bród i smród na ulicach, roztopy, szwargot żydowsko-rosyjski, niepewność sytuacji. [...] jestem zdecydowany wynieść się stąd, tylko nie wiem jeszcze dokąd"31.

W cytowanych już Zapiskach pamiętnikarskich Kolankowski, bezpośredni uczestnik tych wydarzeń, zanotował:

Ale cała ta moja walka, by Uniwersytet Wileński był jednym z uniwersytetów polskich, rzeczą wtórną. Pierwszą była, aby on powstał. I tu muszę [...] stwierdzić, zgodnie z relacją Komitetu Odbudowy, że Ministerstwo Oświaty uniwersytetu w Wilnie przynajmniej w 1919 roku nie chciało ${ }^{32}$.

Kolankowskiego. Życie naukowe Ludwika Kolankowskiego do 1939 roku, [w:] Ludwik Kolankowski: dzieło i życie: indywidualny przypadek historiograficzny, red. P. Oliński, W. Piasek, Toruń 2017, s. 67-68, aneks, dok. 8 (s. 204).

${ }^{29}$ LCVA, F. 175, ap. 1(I)A, b. 12a, k. 3-4v, Protokół nr 1 organizacyjnego posiedzenia Komitetu Wykonawczego przy Uniwersytecie Wileńskim z d[nia] 27-go maja 1919 r. w lokalu Kancelarii Uniwersyteckiej pod przewodnictwem Kuratora Uniwersytetu Profesora L. Kolankowskiego; LCVA, F. 175, ap. 1(I)A, b. 18, Fotografie i życiorysy członków Komitetu Wykonawczego Odbudowy Uniwersytetu Wileńskiego z 1919 r.

${ }^{30}$ LCVA, F. 175, ap. 1(I)A, b. 14, k. 15, Odpis protokołu posiedzenia Polskiej Rady Narodowej z 16 IV 1919 r., tam podano informację o odbyciu przez Stanisława Władyczkę i Władysława Zawadzkiego dwu konferencji w sprawie Uniwersytetu w Wilnie z szefem Nauki i Szkół Wyższych Adamem Wrzoskiem; D. Zamojska, Akademicy i urzędnicy, s. 84.

${ }^{31}$ Cytat za: D. Zamojska, ,, Ta ludność życzy mieć Uniwersytet...”, s. 19-20.

${ }^{32}$ L. Kolankowski, Zapiski pamiętnikarskie, s. 137. 
Z przytoczonego fragmentu Zapisek widać, że L. Kolankowskimu rzeczywiście zależało na szybkim urzeczywistnieniu idei odbudowy wileńskiej wszechnicy.

W pracach nad organizacją uniwersytetu ważna była kwestia liczby i kształtu wydziałów, które miały powstać, oraz znalezienie wykładowców o odpowiednich kwalifikacjach naukowych mogących objąć planowane katedry.

W protokołach Komisji Organizacyjno-Rewindykacyjnej pojawiały się nazwy różnych fakultetów: teologicznego, prawnego, lekarskiego, filologicznego, sztuk pięknych, fizyczno-matematycznego, rolniczego, agronomicznego, weterynaryjnego, farmaceutycznego. A członkowie tej Komisji podzielili się obowiązkami związanymi z organizacją poszczególnych wydziałów ${ }^{33}$. Tak dużej liczbie wydziałów był przeciwny delegat Ministerstwa WRiOP A. Wrzosek, który 21 maja 1919 roku na nadzwyczajnym posiedzeniu Komisji Organizacyjno-Rewindykacyjnej, z udziałem przedstawiciela rządu: naczelnika Wydziału Oświecenia w Komisariacie Generalnym Ziem Wschodnich Władysława Lichtarowicza, Stefana Ehrenkreutza z Warszawy oraz członków Komisji, forsował uczelnię małą, dwuwydziałową, ale „na modłę europejską", taką jak w Poznaniu, gdzie ,[...] ograniczono się narazie do wydziałów: filozoficznego, prawa i administracji”. W trakcie posiedzenia uchwalono, by po porozumieniu się z L. Kolankowskiem, jako urzędowym organizatorem Uniwersytetu Wileńskiego, prosić Komisariat Generalny Ziem Wschodnich o mianowanie ,,[...] w czasie jak najbliższym t.j. jeszcze w maju - Komitetu Wykonawczego dla objęcia pod pieczę i pod swój zarząd gmachów Uniwersyteckich i zarządzenia ich wyrestaurowaniem". Z tą koncepcją nie zgadzał się A. Wrzosek, który uważał, że Komitet Wykonawczy powinien powstać w porozumieniu z Ministerstwem i składać się z ograniczonej liczby osób. Sugerował też konieczność uwzględnienia na wydziale literacko-humanistycznym zajęć „z języków miejscowych: białoruskiego i litewskiego". Spotkało się to ze zdecydowanym oporem członków Komisji, którzy odwołali się do „odstraszającego przykładu Lwowa, gdzie podobne postępowanie doprowadziło do niesnasek, a nawet burd wśród uczącej się młodzieży”. Wówczas też powzięto postanowienie o „,...] pilnym otwarciu wydziałów filozoficznego i prawnego. Opracowano projekt Statutu Uniwersyteckiego, Preliminarze i Listę ciała profesorskiego". Ponadto skierowano prośbę do władz państwowych o wyasygnowanie odpowiednich funduszy na pensje dla urzędników i personelu pomocniczego, druki czy przybory kancelaryjne ${ }^{34}$.

Najtrudniej było skompletować kadrę profesorską, która zechciałaby porzucić uczelnie w Polsce i przenieść się do Wilna, którego status prawny nadal nie był jasny. Kłopoty kadrowe nowej uczelni skłaniały Ministerstwo WRiOP do opowiadania się za tymczasową rezygnacją z jej uruchomienia lub też za otwarciem jej w formie okrojonej do wydziału filozoficznego (humanistycznego) i być może prawniczego. Oba te fakultety pojmowano jednak ściśle utylitarnie, jako szkołę kształcącą polskich nauczycieli i urzędników, która nie będzie posiadała pełnych praw akademickich. Swoje stanowisko władze ministerstwa wyrazily expressis verbis 14 czerwca 1919 roku w czasie

${ }^{33}$ LCVA, F. 175, ap. 1(I)A, b. 13, k. 31-32v, k. 35-36, Protokoły posiedzenia nr pięć (z 12 maja 1919), nr sześć (z 19 maja 1919) Komisji organizacyjno-rewindykacyjnej; LCVA, F. 175, ap. 1(I)A, b. 14, k. 22-23, Protokół posiedzenia Komisji dla organizacji Wydziału Weterynaryjnego Uniwersytetu Wileńskiego, odbytego d. 12 sierpnia 1919 r. w składzie lekarzy weterynarii.

${ }^{34}$ LCVA, F. 175, ap. 1(I)A, b. 13, k. 40-46, Protokół nadzwyczajnego posiedzenia (z kolei siódmego) Komisji Organizacyjno-rewindykacyjnej Uniwersytetu Wileńskiego z d. 21 maja 1919 r. w lokalu t.cz. Kancelarii Uniwersytetu; LCVA, F, 175, ap. 1(I)A, b. 5, k. 10, zaproszenie członków Komisji organizacyjno-rewindykacyjnej na nadzwyczajne posiedzenie, które odbędzie się we środę 21 maja 1919 r. w Kancelarii Uniwersyteckiej przy ul. Świętojańskiej 26. 
konferencji, która odbyła się u Ministra Wyznań Religijnych i Oświecenia Publicznego Jana Łukasiewicza z udziałem Ludwika Kolankowskiego, historyka Uniwersytetu Wileńskiego Józefa Bielińskiego oraz członków Tymczasowego Senatu Akademickiego: rektora Józefa Ziemackiego, Alfonsa Parczewskiego, Stanisława Ptaszyckiego, Stanisława Władyczki, Kazimierza Noiszewskiego, Władysława Zawadzkiego, i spowodowało ostrą reakcję Wilnian. W ich imieniu S. Władyczko odpowiedział, że

[...] Uniwersytet polski w Wilnie jako najważniejsza placówka polskości na kresach wschodnich jest kwestią tak palącą i tak na czasie, że nie mamy chwili do stracenia i musimy wyzyskać dzisiejsze warunki polityczne, żeby Uniwersytet formalnie już od jesieni był czynny ze wszystkimi wydziałami, chociażby w stadium organizacji. [...] To nie Warszawa, nie Kraków, Lwów tam urządza Uniwersytet Polski, ale ta ludność polska od wieków tam zamieszkała, ta ludność, która zapomnieć nie może, że w murach tych wykładali Śniadeccy, że z murów tych wyszli Mickiewicz i Słowacki. [...] Ta ludność życzy mieć uniwersytet, a nie wyższą uczelnię humanistyczną lub liceum, jak to proponuje p. Szef Wrzosek.

Wilnianie wskazali na ryzyko związane $\mathrm{z}$ odwlekaniem uruchomienia uczelni w niepewnej sytuacji politycznej i konieczność jej otwarcia ze wszystkimi wydziałami już w październiku tego roku. Tylko dzięki zdecydowanej postawie i wypowiedzi uczestniczącego w spotkaniu Kolankowskiego, który powołując się na wolę Naczelnego Wodza, opowiedział się za otwarciem na jesieni uczelni ze wszystkimi planowanymi wydziałami, osiągnięto porozumienie ${ }^{35}$.

W przemówieniu wygłoszonym 11 października 1919 roku, w trakcie pierwszej, uroczystej inauguracji roku akademickiego we Wszechnicy Wileńskiej, Adam Wrzosek powiedział:

[...] Zapał i ofiarna praca dokonały w ciągu kilku miesięcy tego, że oto dziś obchodzimy uroczyście ponowne otwarcie Uniwersytetu, który w ubiegłym stuleciu oddał ojczyźnie takie usługi, jakich nie oddał żaden inny uniwersytet polski. Miałem szczęście być świadkiem tej mozolnej, lecz pełnej młodzieńczego rozmachu pracy, od pierwszych chwil aż do ostatnich. Nie wiem, jak dziękować mam Naczelnikowi Państwa za popieranie wszelkiej inicjatywy w tem dziele? [...] Czy bezustanną pracę tych, którzy z rektorem Siedleckim i profesorem Ziemackim na czele wszelkich starań dokładali, aby jak najrychlej przybliżyć dzień otwarcia Uniwersytetu. Wspólnymi zabiegami, dobrą wolą i poświęceniem powstała ta Szkoła Główna. [...] I oto została odbudowana nauki polskiej twierdza.

Pominął i zdeprecjonował więc rolę Ludwika Kolankowskiego w kwestii wskrzeszenia wileńskiej uczelni ${ }^{36}$.

Najważniejszą kwestią zaprzątającą głowy organizatorów uniwersytetu był brak wykładowców o odpowiednich kwalifikacjach naukowych mogących objąć planowane

${ }^{35}$ LCVA, F. 175, ap. 1(I)A, b. 14, k. 66-70v, Notatki do protokołu posiedzenia w sprawie Uniwersytetu Wileńskiego w Ministerstwie Wyznań Religijnych i Oświecenia Publicznego, dn. 14 czerwca 1919 r. w Warszawie. Swoje stanowisko A. Wrzosek powtórzył na wspomnianym posiedzeniu, na którym ponownie opowiedział się „,[...] za możnością otwarcia tylko Wydziału Humanistycznego, wobec braku kandydatów na katedry wydziału prawnego i absolutnej niemożliwości zorganizowania wydziału lekarskiego [...]”. Ponadto w protokole zaznaczono, że ,[...] będą bezwarunkowo czynne wydziały humanistyczny i prawa, inne zaś (rolniczy, przyrodniczy, lekarski, weterynaryjny) w stadjum organizacji”; S. Władyczko, Pierwszy okres prac organizacyjnych, s. 38-39.

${ }^{36}$ LCVA, F. 175, ap. 1(I))A, b. 19, k. 63-64, Przemówienie Szefa Sekcji Szkół Wyższych Prof. Dr Adama Wrzoska w czasie uroczystego otwarcia wskrzeszonej Wszechnicy Wileńskiej w dniu 11 października 1919 r. 
katedry. Już w początkowym okresie działalności Tymczasowy Senat Akademicki prowadził pertraktacje $\mathrm{z}$ uczonymi z różnych dzielnic Polski oraz tymi, którzy pracowali za granicą. Do rozmów z uczonymi polskimi pracującymi w Rosji Senat delegował Stanisława Władyczkę, który odbył podróż do tamtejszych miast uniwersyteckich i proponował objęcie katedr w Wilnie. Wydaje się, że wynik tych poszukiwań rozczarował Senat. Dlatego też w początkach maja Komitet Organizacyjno-Rewindykacyjny na kolejnym posiedzeniu wydelegował ks. Leona Puciatę do ośrodków uniwersyteckich w Polsce i za granicą w celu poszukiwania kandydatów na wykładowców Wydziału Teologicznego, asygnując na ten cel 1000 marek polskich. Wspomnianą podróż do Warszawy, Lublina, Lwowa, Krakowa i Poznania ks. Puciata odbył od 7 do 30 lipca 1919 roku. Kosztowała 2000 marek polskich, o czym informował on Senat Akademicki w liście z 17 kwietnia 1921 roku $^{37}$.

Już 27 maja na pierwszym posiedzeniu Komitetu Wykonawczego Odbudowy Uniwersytetu Wileńskiego L. Kolankowski zaproponował utworzenie komisji naukowej personalno-kwalifikacyjnej, która miała odpowiadać za obsadę kadrową tworzonych w Wilnie katedr. W jej skład mieli wchodzić: delegat Ministerstwa WRiOP, po dwóch delegatów Senatów Akademickich: Uniwersytetu Jagiellońskiego, Uniwersytetu Lwowskiego i Uniwersytetu Warszawskiego, oraz trzech przedstawicieli Tymczasowego Senatu Akademickiego Uniwersytetu Wileńskiego, tj. Józef Ziemacki, Stanisław Władyczko i Stanisław Kościałkowski. Postanowiono także, że jeszcze w czerwcu tego roku zostanie wystosowane pismo do senatów uniwersytetów polskich z prośbą, by wsparły kadrę przyszłego Uniwersytetu Wileńskiego. Rozważano również możliwość zatrudnienia w Wilnie naukowców polskich pracujących za granicą: w Niemczech, Francji, Szwajcarii, Belgii, Anglii ${ }^{38}$. Nie ulega wątpliwości, że w negocjacjach powoływano się bardziej na tradycję i historię dawnego Uniwersytetu niż na możliwości mieszkaniowo-finansowe. W konsekwencji 4 lipca w Warszawie w trakcie I zjazdu przedstawicieli polskich szkół wyższych, który odbył się pod przewodnictwem byłego rektora UJ Kazimierza Kostaneckiego, z sukcesem przeprowadzono negocjacje dotyczące spraw kadrowych i obsady katedr w nowo tworzonej uczelni. Delegatami uczelni wileńskiej na zjeździe byli: rektor J. Ziemacki, S. Władyczko i Ferdynand Ruszczyc. Obecni tam przedstawiciele uczelni z Lwowa i Krakowa przyjęli uchwałę, w której zgodzili się urlopować na rok kilku swoich profesorów, by mogli oni czasowo objąć katedry w Wilnie. Zwłaszcza nieoceniona była pomoc ze strony Uniwersytetu Jagiellońskiego, który zasilił Wilno sporą grupą nauczycieli akademickich, wśród nich znalazł się m.in. Michał Siedlecki — pierwszy rektor wileńskiej uczelni. 31 lipca w czasie kolejnego posiedzenia Komisji OrganizacyjnoRewindykacyjnej rektor Ziemacki złożył sprawozdanie z pobytu w Warszawie w związku z pracami nad wskrzeszeniem Uniwersytetu w Wilnie oraz poruszył kwestie obsadzania katedr i zgody na ich objęcie ${ }^{39}$.

${ }^{37}$ LCVA, F. 175, ap. 1(I)A, b. 13, k. 31v-32, Protokół piątego posiedzenia Komisji organizacyjno-rewindykacyjnej Uniwersytetu Wileńskiego z d[nia] 12 maja 1919 r. w mieszkaniu D-ra Zahorskiego; LCVA, F. 175, ap. 1(I)A, b. 48, k. 299, Sprawy budżetowe 1920/21, pismo ks. L. Puciaty do Prześwietnego Senatu i Rektoratu Uniwersytetu Stefana Batorego z 17 kwietnia 1921 r. Zob. też: S. Władyczko, Pierwszy okres prac organizacyjnych, s. 41-42.

${ }^{38}$ LCVA, F. 175, ap. 1(I)A, b. 12a, k. 3-4v, Protokół nr 1 organizacyjnego posiedzenia Komitetu Wykonawczego przy Uniwersytecie Wileńskim z d[nia] 27-go maja 1919 r. w lokalu Kancelarii Uniwersyteckiej pod przewodnictwem Kuratora Uniwersytetu Profesora L. Kolankowskiego. Zob. też: A. Wrzosek, Wskrzeszenie Uniwersytetu Wileńskiego, s. 14, 16-17.

${ }^{39}$ LCVA, F. 175, ap. 1(I)A, b. 13, k. 64-66, Protokół Nr 10 posiedzenia Komisji Organizacyjno-Rewindykacyjnej Uniwersytetu Wileńskiego z dnia 31 lipca 1919 r. o godz. 18-tej w Kan- 
Ludwik Kolankowski, pełnomocnik do spraw odbudowy Uniwersytetu Wileńskiego, tak wspominał swoją ówczesną współpracę z ministerstwem i Adamem Wrzoskiem przy doborze kadry dla przyszłej uczelni:

[...] Do wielu trudności ze strony ministerstwa zaliczyć muszę także niechętne traktowanie otwarcia niektórych wydziałów, np. Sztuk Pięknych, Prawnego, Teologicznego, Lekarskiego. Co do pierwszego opozycja ministerstwa była zasadnicza, co do dwóch następnych oparta na względach personalnych. Pod pozorem, że nie można znaleźć odpowiednich kandydatów na dziekanów-organizatorów tych trzech ostatnich wydziałów (dla sztuk Pięknych był znakomity Ruszczyc), odrzucając wymienione przeze mnie kandydatury prof. Parczewskiego, prof. Władyczki i ks. Żongołłowicza [...] opóźniało ministerstwo wszystko i uległo częściowo dopiero pod naciskiem zbliżania się jesieni ${ }^{40}$.

Mimo że w dekrecie nominacyjnym Kolankowskiego zaznaczono, że ma prowadzić „działanie w sprawach wyboru personelu profesorskiego w porozumieniu z Ministerstwem Oświaty i Wyznań w Warszawie”, na posiedzeniu Rady Ministrów 16 lipca 1919 roku, dla dobra powierzonego mu przez Józefa Piłsudskiego projektu (aczkolwiek bez porozumienia z Naczelnym Wodzem), złożył on na ręce ministerstwa uprawnienia do powoływania profesorów i de facto przelał swe pełnomocnictwo na Ministerstwo WRiOP. Szef Departamentu Nauki i Szkół Wyższych A. Wrzosek wykorzystał tę sytuację i odsunął Kolankowskiego od wpływu na dalszą organizację Uniwersytetu w Wilnie i obsadę katedr, starając się zminimalizować i zdezawuować jego wcześniejsze prace. Ów dystans do Pełnomocnika widoczny jest także w tekście $O$ wskrzeszeniu Uniwersytetu Wileńskiego w roku 1919 zamieszczonym drugim tomie Księgi Pamiątkowej ku uczczeniu CCCL rocznicy założenia i X wskrzeszenia Uniwersytetu Wileńskiego, w którym Wrzosek pominął udział Kolankowskiego we wskrzeszenia USB, pisząc, że:

[...] Zarówno minister oświaty prof. Jan Łukasiewicz jak i szef Sekcji Szkół Akademickich byli gorącymi zwolennikami jak najrychlejszego wznowienia Uniwersytetu Wileńskiego, i to, o ile możności, w dawnej jego świetności naukowej ${ }^{41}$.

Nie ulega jednak wątpliwości, że to Kolankowski, wbrew intencjom Ministerstwa, doprowadził do powstania wielowydziałowej uczelni w Wilnie. Rację ma Joanna Gierowska-Kałłaur, pisząc, że:

celarii Un[iwersyteckiej], w trakcie tego posiedzenia rektor Ziemacki omówił zjazd profesorów oraz efekty rozmów prowadzonych w czasie pobytu w Warszawie, przedstawił także nazwiska osób, które zgodziły się objąć katedry na kilku wydziałach wskrzeszanej w Wilnie uczelni. Zob. też: F. Ruszczyc, Dziennik, cz. 2: W Wilnie 1919-1932, wybór, układ, opracowanie, wstęp i posłowie E. Ruszczyc, Warszawa 1996, s. 17-22. Ruszczyc, naoczny świadek tych wydarzeń, opisał m.in. posiedzenia Komitetu Organizacyjnego z 19 i 23 czerwca 1919 r. w Wilnie, wyjazd do Warszawy 25 czerwca oraz rozmowy w Ministerstwie WRiOP; A. Wrzosek, Wskrzeszenie Uniwersytetu Wileńskiego, s. 14; D. Zamojska, Akademicy i urzędnicy, s. 95-96; Taż, Konferencje rektorów szkót akademickich $w$ Polsce $w$ okresie międzywojennym: reprezentacja środowiska akademickiego wobec zmian ustawodawstwa, Rozprawy z Dziejów Oświaty 2004 t. 43, s. 115120. Pierwszy zjazd rektorów odbył się w Warszawie od 28 czerwca do 4 lipca 1919 r. Więcej informacji na temat zjazdów rektorów znajduje się w pracy: Konferencje Rektorów Szkót Akademickich $w$ Polsce $w$ latach 1919-1931: protokóly narad, uchwaly i memorialy, ze wstępem S. Estreichera, red. L. Zembrzuski, Warszawa 1932.

${ }^{40}$ L. Kolankowski, Zapiski pamiętnikarskie, s. 141-142.

${ }^{41}$ Tamże, s. 138-139. Zob. też: A. Wrzosek, Wskrzeszenie Uniwersytetu Wileńskiego, s. 10. Rolę Kolankowskiego przy restytucji Uniwersytetu w Wilnie opisała Dorota Zamojska w artykule „Ta ludność życzy mieć uniwersytet... ”, passim. 
[...] bez względu na osobiste przekonania, jakiekolwiek one były, [Kolankowski] lojalnie realizował program obowiązujący na terenie podległym Zarządowi Cywilnemu Ziem Wschodnich i dlatego nie dopuszczał do ingerencji Warszawy.

Wrogość A. Wrzoska do L. Kolankowskiego przekładała się także na niechęć tego pierwszego wobec kandydatów na stanowiska profesorskie i dziekańskie, zaakceptowanych przez Kolankowskiego ${ }^{42}$.

W konsekwencji odpowiedzialność za sytuację kadrową nowego uniwersytetu wzięło na siebie ministerstwo. Po 16 lipca to Wrzosek decydował o obsadzie personalnej katedr na wskrzeszonej w Wilnie uczelni, której rektorem został Michał M. Siedlecki, zoolog z UJ, a nie zasłużony dla jej reaktywacji Józef Ziemacki ${ }^{43}$.

Jednocześnie ze sprawą obsady etatów naukowych prowadzone były intensywne prace nad opracowaniem projektu statutu przyszłego uniwersytetu. Według sprawozdania S. Władyczki sporządzono wówczas aż trzy projekty statutu, w których m.in. przewidziano zamiast jednego wydziału filozoficznego dwa odrębne wydziały: matematyczno-przyrodniczy i humanistyczny. W pracach nad statutem uczestniczyli profesorowie: J. Ziemacki i S. Władyczko. W protokołach Komisji Organizacyjno-Rewindykacyjnej poza wydziałami: teologicznym, prawa i lekarskim, wymieniane były też fakultety: filologiczny, sztuk pięknych, fizyko-matematyczny, agronomiczny, weterynaryjny, farmaceutyczny i stomatologiczny ${ }^{44}$.

Członkowie Komitetu Wykonawczego: J. Ziemacki, W. Zahorski, Bronisław Umiastowski, Zygmunt Nagórski i Ludwik Wasilewski, 2 sierpnia zostali przyjęci przez przebywającego w Wilnie Józefa Piłsudskiego. W trakcie tego posłuchania poruszano m.in. sprawy związane z gmachami, które miała otrzymać tworząca się uczelnia, oraz dekretem otwarcia Uniwersytetu. Naczelnik stwierdził wówczas, że:

[...] dekret może być wydany tylko wtedy, jak mu będzie przedstawione ciało profesor-

skie w składzie: Rektora, prorektora i dziekanów wydziałów, choćby były przeszkody

42 J. Gierowska-Kałłaur, Zarząd Cywilny Ziem Wschodnich, s. 112; Taż, Między polityka a nauka, s. 38-39; R. Jurkowski, U źródet Uniwersytetu Stefana Batorego - początki Wydziatu Teologicznego (1918-1920), Echa Przeszłości 2017, t. 18, s. 242.

${ }^{43}$ Z. Opacki, Środowisko naukowe USB $w$ Wilnie wobec polsko-litewskiego sporu terytorialnego o Wileńszczyznę w latach 1919-1922, [w:] Polacy $i$ sąsiedzi-dysonanse $i$ przenikanie kultur, cz. 2: zbiór studiów, red. R. Wapiński, Gdańsk 2001, s. 179-181; A. Wrzosek, Wskrzeszenie Uniwersytetu Wileńskiego, s. 11, 21-23, 27; S. Władyczko, Pierwszy okres prac organizacyjnych, s. 43, napisał, że „Od dn. 20 sierpnia 1919 r. decydującym czynnikiem w wyborze profesorów było wyłącznie Ministerstwo W.R.iO.P. w osobie szefa Sekcji Nauki i Szkół Wyższych prof. Adama Wrzoska. Wtenczas została definitywnie ustalona lista ciała profesorskiego dla wszystkich wydziałów".

${ }^{44}$ LCVA, F. 175, ap. 1(I)A, b. 13, k. 65, Protokół nr 10 posiedzenia Komisji OrganizacyjnoRewindykacyjnej Uniwersytetu Wileńskiego z dnia 31 lipca 1919 r. o godz. 18-tej w Kancelarii Un[iwersyteckiej]; S. Władyczko, Pierwszy okres prac organizacyjnych, s. 45-46; D. Zamojska, „,Ta ludność życzy mieć uniwersytet...”, s. 22-25, opisała projekty statutu przygotowywanego dla Uniwersytetu Wileńskiego; Taż, Akademicy i urzędnicy, s. 86, 109, powstałe w środowisku wileńskim projekty statutowe nawiązywały do tradycji rosyjskiej (np. schemat wydziałów, kompetencje rektora itp.). Zob. też.: A. Wrzosek, Wskrzeszenie Uniwersytetu Wileńskiego, s. 12, 30 31, wspominał że J. Ziemacki ułożył statut, według którego Uniwersytet Wileński miał posiadać aż dziesięć wydziałów (rzymsko-katolicki, ewangelicko-reformowany, prawa i administracji, humanistyczny, pedagogiczny, matematyczno-przyrodniczy, lekarski, weterynaryjny, agronomiczno-leśny i sztuk pięknych) i cztery „pododdziały" (ekonomiczno-polityczny i konsularny, języków wschodnich, farmaceutyczny i odontologiczny). 
dla faktycznego otwarcia Uniwersytetu w bieżącem półroczu. Podkreślone było, że w tym dekrecie powinno być wyrażone nazwisko prof. Kolankowskiego, jako organizatora Uniwersytetu Wileńskiego.

Już 3 sierpnia 1919 roku Generalny Komisarz Ziem Wschodnich Jerzy Osmołowski, najpewniej na rozkaz Piłsudskiego, przyznał nowo tworzonej uczelni kilkanaście nieruchomości. Był to m.in. tzw. gmach główny dawnego Uniwersytetu, była szkoła junkrów przy ul. Zakretowej 23, gmach byłej szkoły techniczno-chemicznej przy ul. Nowogródzkiej 22, mury poaugustiańskie z koszarami i pobernardyńskie z przyległościami, koszary pojezuickie przy kościele św. Ignacego, dom przy ul. Zamkowej 26, folwark Zakret. Dostateczna liczba budynków pozwoliła myśleć o uczelni wielowydziałowej ${ }^{45}$.

Z 5 sierpnia pochodzi telegram Komitetu Wykonawczego wysłany do szefa Sekcji Nauki i Szkół Wyższych A. Wrzoska i pełnomocnika L. Kolankowskiego z informacją, że

Generalny Komisarz Osmołowski zażądał od nas natychmiastowego przedstawienia nazwisk członków Senatu dla dekretu mamy zamiar podać następujące nazwiska Organizator Kolankowski, Rektor Ziemacki, dziekan teologii ksiądz Żongołłowicz, prawa Parczewski, humanistyki Godlewski [!], lekarski Władyczko, sztuk pięknych Ruszczyc. Prosimy Ministerstwo o telegraficzne zatwierdzenie lub zmianę. Naczelnikowi Państwa bardzo zależy ażeby dekret był wydany przed wyjazdem jego z Wilna co nastąpi ósmego sierpnia $^{46}$.

W trakcie 20. posiedzenia Komitetu Wykonawczego, które odbyło się 9 sierpnia, omawiano m.in. sprawy dotyczące powołania komisji, która zajęłaby się sprawami związanymi z uroczystością otwarcia Uniwersytetu. W poniedziałek 11 sierpnia odbyło się spotkanie komisji zaproszeniowej i obchodu uroczystości otwarcia Uniwersytetu. W skład tej ostatniej wchodzili: hrabia Antoni Tyszkiewicz (prezes) oraz Ferdynand Ruszczyc i Władysław Zahorski. Kilka dni później, 14 sierpnia, Ruszczyc wysłał list do przebywającego w Warszawie L. Kolankowskiego w sprawie insygniów dla nowej uczelni, które miał projektować ${ }^{47}$.

W ogłoszeniach podawanych do prasy lokalnej i ogólnopolskiej 16 sierpnia znalazła się informacja, że uroczyste otwarcie uczelni odbędzie się 4 października 1919 roku i obejmie następujące wydziały: prawo, teologię, medycynę, humanistykę, przyrodę (z wydziałem rolnictwa i leśnictwa) i sztuki piękne ${ }^{48}$. Wielkość nowego Uniwersytetu podkreślał także, wydrukowany po 19 sierpnia w ukazującym się w Wilnie dzienniku „Nasz Kraj”, artykuł Jakie znaczenie ma dla Wilna Uniwersytet:

[...] A jest jeszcze jeden trzeci wzgląd, który przemawia zaliczną (sic!) frekwencją Uni-

${ }^{45}$ LCVA, F. 175, ap. 1(I)A, b. 12a, k. 56-56v, Protokół posłuchania z d[nia] 2 VIII 1919 r. u Naczelnika Państwa p. Józefa Piłsudskiego, danego Komitetowi Wykonawczemu Odbudowy Uniwersytetu Wileńskiego; LCVA, F. 175, ap. 1(I)A, b. 12a, k. 59-60, Protokół Nr 15 posiedzenia Komitetu Wykonawczego z dnia 3 sierpnia 1919 r. Zob. też: A. Wrzosek, Wskrzeszenie Uniwersytetu Wileńskiego, s. 17-18, wyliczył tam wszystkie nieruchomości przyznane tworzonemu Uniwersytetowi; S. Władyczko, Pierwszy okres prac organizacyjnych, s. 46-48, 51.

${ }^{46}$ LCVA, F. 175, ap. 1(I)A, b. 4, k. 6, Odpis depeszy do prof. prof. Wrzoska i Kolankowskiego z 5 VIII 1919 r. w sprawie wykazu członków Senatu.

${ }^{47}$ LCVA, F. 175, ap. 1(I)A, b. 12a, k. 67-68v, Protokół Nr 20 z posiedzenia Komitetu Wykonawczego Odbudowy Uniwersytetu Wileńskiego w dn[iu] 9 sierpnia 1919 r. w Kancelarji Uniwersyteckiej o godz. 10-tej; F. Ruszczyc, Dziennik, cz. 2: W Wilnie, s. 32, przypis 1, 2.

${ }^{48}$ LCVA, F. 175, ap. 1(I)A, b. 9, k. 19, 20, pisma Sekretariatu Uniwersytetu w sprawie zapisów na studia oraz terminu otwarcia; LCVA, F. 175, ap. 1(I)A, b. 7, k. 10, J[ózef] Z[iemacki], Służba młodzieży w wojsku a Uniwersytet Wileński (maszynopis artykułu wysłanego do kilku do gazet). 
wersytetu Wileńskiego i o którym warto wspomnieć, a który aby miał największe znaczenie. A mianowicie - ciche ale poważne swą historią i tak wielką swą historyczną tradycją Wilno posiada wszelkie dane, aby być Atenami Polskiemi. Nie gwarna Warszawa, nie Lwów buńczuczny, nie Poznań i nie Lublin, nie posiadający tradycji Uniwersyteckich, sprzyjać będą młodzieży w skupieniu ducha i w ześrodkowaniu wysiłków woli dla osiągnięcia najwyższych wyrazów nauki. Wilno posiada tradycje filaretów i filomatów, wcale nie przypadkowo w Wilnie sto lat temu tworzyły się te sławne filareckie stowarzyszenia. Tworzyły się one, bo tu była gleba po temu. I miejmy nadzieję, że gleba ta po 87 letnim dyrwanie (ugorze) pozostanie jeszcze wydatniejszą i że młodzież najpoważniejsza w Polsce i najbardziej pracowita zechce zjeżdżać się na studia do Wilna ${ }^{49}$.

Doniosłość tego wydarzenia odczuwali także jego twórcy. W kartce z 20 sierpnia 1919 roku do Ludwika Wasilewskiego rektor Ziemacki pisał:

[...] Sprawy układają się dobrze. Już w tych dniach wyjdą dekrety, stanowiące o Uniwersytecie. Będziecie płakać z radości, jak ja mam ciągle łzy w oczach, że mi danem było dożyć tej chwili. Otwarcie odbędzie się 1 października, lub nawet wcześniej ${ }^{50}$.

W podobnym tonie był list Ziemackiego do F. Ruszczyca z 19 sierpnia:

[...] Już wszystko jest ustalone, co się tyczy senatu i dekretu stwierdzającego otwarcie Uniwersytetu. Uroczystość odbędzie się najpóźniej 4 X, a może i o tydzień wcześniej. Moje najgorętsze pragnienie współpracy z szanownym i kochanym Profesorem — zdaje się — już spełnione. [...] Oczekujemy tu Profesora z niecierpliwością. Potrzeba robić insygnia. Pieczęć w wosku już oczekuje Profesora. Trzeba drukować zaproszenia i je rozsyłać ${ }^{51}$.

Mające za kilka dni nastąpić ogłoszenie przez Naczelnika Państwa dekretu o wskrzeszeniu Uniwersytetu w Wilnie spowodowało zakończenie prac Warszawskiego Komitetu Odbudowy Wszechnicy Wileńskiej. W niedzielę 24 sierpnia wydał on Odezwę do Społeczeństwa Polskiego wyrażającą radość z powstania uczelni w Wilnie. Dokument podpisali przewodniczący Alfons Parczewski i członkowie: Józef Ziemacki, Józef Bieliński, Ignacy Baliński, Ferdynand Ruszczyc, Stanisław Władyczko, Władysław Zawadzki, Kazimierz Noiszewski ${ }^{52}$.

W przeddzień ogłoszenia przez Józefa Piłsudskiego dekretu o wskrzeszeniu wileńskiej uczelni ukazała się odezwa Uniwersytet a Wilno, w której napisano:

Uroczystość otwarcia wskrzeszonego Uniwersytetu będzie jednem z najpiękniejszych Świąt w wyzwolonym w cudowny sposób Wilnie. Społeczeństwo tutejsze powinno się godnie przygotować. Niewątpliwie społeczność polska kresowa godnie wywiąże się z zadania. Ale czas już wielki żeby rozpocząć przygotowania. Podajemy do ogólnej wiadomości, że pod przewodnictwem Antoniego hrabiego Tyszkiewicza już się utworzył Komitet Obchodu Uroczystego Otwarcia Uniwersytetu Wileńskiego. Ktokolwiek zechce przyczynić się radą lub wskazówkami lub ofiarować swą współpracę i przyjść z pomocą czynną niech się zwróci do Komitetu Wykonawczego Odbudowy Uniwersytetu Wileńskiego w godzinach porannych od 10-1-ej codziennie prócz Świąt ${ }^{53}$.

${ }^{49}$ LCVA, F. 175, ap. 1(I)A, b. 7, k. 17-18, ,Jakie znaczenie ma dla Wilna Uniwersytet 19 sierpnia 1919 r.” (maszynopis artykułu do dziennika „Nasz Kraj”).

${ }^{50}$ LCVA, F. 175, ap. 1(I)A, b. 4, k. 21-21v, kartka J. Ziemackiego do Ludwika Wasilewskiego.

${ }^{51}$ Zob.: F. Ruszczyc, Dziennik, cz. 2: W Wilnie, s. 33.

${ }^{52}$ S. Władyczko, Pierwszy okres prac organizacyjnych, s. 56-58, zamieścił tam całą odezwę; F. Ruszczyc, Dziennik, cz. 2: W Wilnie, s. 34, przypis 2.

${ }^{53}$ LCVA, F. 175, ap. 1(I)A, b. 7, k. 19, „Uniwersytet a Wilno 27 sierpnia 1919 r.” (brulion odezwy). 
Nie ulega wątpliwości, że tylko dzięki energii i oddaniu dla „sprawy uniwersytetu” przedstawicieli inteligencji wileńskiej i Ludwika Kolankowskiego, możliwe było dotrzymanie terminów i otwarcie uczelni na jesieni 1919 roku.

Naczelny Wódz wydał 28 sierpnia dekret powołujący do życia Uniwersytet Stefana Batorego (Universitas Batoreana Vilnensis) z nominacjami pierwszego Senatu Akademickiego. Józef Piłsudski podpisał tekst różny od tego, który przygotował wcześniej tymczasowy rektor Józef Ziemacki. Jego autorem był Adam Wrzosek. Z dniem 1 września J. Piłsudski mianował pierwszych członków Senatu Akademickiego w osobach: rektora Michała Siedleckiego, prorektora Józefa Ziemackiego, dziekana Wydziału Teologicznego ks. Bronisława Żongołłowicza, dziekana Wydziału MatematycznoPrzyrodniczego Piotra Wiśniewskiego, dziekana Wydziału Sztuk Pięknych Ferdynanda Ruszczyca oraz Władysława Mickiewicza, syna Adama, jako profesora honorowego historii literatury polskiej w Uniwersytecie Stefana Batorego ${ }^{54}$.

Michał Siedlecki, profesor zoologii z Uniwersytetu Jagiellońskiego, tak wspominał swoją nominację i narady w Warszawie w sprawie organizacji wileńskiej uczelni:

[...] Kiedy otrzymałem wiadomość, że zostałem już zamianowany pierwszym Rektorem Uniwersytetu Wileńskiego, przedstawiłem się Józefowi Piłsudskiemur podówczas Naczelnikowi Państwa, i miałem z nim krótką, ale bardzo miłą rozmowę. Zupełnie zgodnie przyszliśmy obaj do przekonania, że Uniwersytet Wileński musi być placówką kultury nawskroś polskiej, ale równocześnie powinien być ogniskiem, promieniującem na kraje sąsiednie. [...] Około 18 sierpnia 1919 r. odbyło się posiedzenie u Naczelnego Komisarza Ziem Wschodnich p. Osmołowskiego, na którem ustaliliśmy ostatecznie datę otwarcia Uniwersytetu na dzień 10 i 11 października tego samego roku.

A tak opisał przyjazd do Wilna i pierwsze dni pobytu w tym mieście:

[...] Około 20 sierpnia 1919 r. mała gromadka, złożona zaledwie z 11 osób, które miały pełnić funkcje naukowe w Uniwersytecie Wileńskim, wyruszyła z Warszawy do Wilna. Prócz mnie znajdował się tam ks. prof. Żongołłowicz, prof. Alexandrowicz, prof. Patkowski, prof. Wiśniewski, Sławiński, dwaj bracia Dziewulscy i dr. Wilczyński, prof. Staniewicz i śp. dr. Horodyski. [...] Ponieważ nie byłem jeszcze bardzo znany w Wilnie, więc miałem sposobność rozmawiania na ulicy i w sklepach z prostymi ludźmi, którzy nie znali wcale mej roli. Wszyscy byli przejęci tem, że Uniwersytet powstaje na nowo. Lud prosty mówił o tem jakby o jakiemś wielkiem święcie. $Z$ wyrażeń tych prostych ludzi bił tak głęboki patrjotyzm, tak wielkie przywiązanie do Polski i taka miłość do tej instytucji, która miała na nowo odżyć, że tłumaczyć ją sobie mogę tylko wrodzoną u tych ludzi głębią uczucia i wspomnieniami tradycji dawnego Uniwersytetu Wileńskiego, która wcale jeszcze nie zagasła ${ }^{55}$.

Kadrę USB w pierwszym roku działalności nowej uczelni w większości stanowili profesorowie z Uniwersytetów: Jagiellońskiego i Warszawskiego. Do momentu przy-

${ }^{54}$ LCVA, F. 175, ap. 1(I)A, b. 944, k. 170-176, Nominacje członków pierwszego Senatu Akademickiego; A. Wrzosek, Wskrzeszenie Uniwersytetu Wileńskiego, s. 21-23. Uczelnia uzyskała ponadto prawo używania pieczęci z wyobrażeniem Orła z Koroną oraz herbem Pogoni Litewskiej w środku. Pierwszym rektorem odnowionego Uniwersytetu pierwotnie miał zostać Ferdynand Ruszczyc — zob.: F. Ruszczyc, Dziennik, cz. 2: W Wilnie, s. 33 - wspominał o tym w liście z 19 sierpnia 1919 r. Józef Ziemacki; Tamże, s. 39, przypis 1, zapis pod datą 10 IX 1919 r. — pisał o nominacjach członków Senatu Akademickiego (Nasz Kraj 1919 nr 117). Zob. też: L. Kolankowski, Zapiski pamiętnikarskie, s. 143-144, który na stanowisko rektora proponował historyka Stanisława Smolkę.

${ }^{55}$ M. Siedlecki, Wspomnienia z pierwszych dwu lat organizacji Uniwersytetu Wileńskiego, s. $62-66,73$. 
bycia do Wilna rektora Siedleckiego sprawami związanymi z organizacją uczelni kierował Tymczasowy Senat na czele z Józefem Ziemackim. Jednak to Ministerstwo miało decydujący wpływ na skład osobowy pierwszego Senatu tworzonego Uniwersytetu. Wspominał o tym w dekrecie nominacyjnym Józef Piłsudski, który zaznaczył, że Ministerstwo WRiOP organizujące w porozumieniu z nim Uniwersytet Wileński przedłożyło mu pismem z 25 sierpnia 1919 roku nazwiska członków Senatu Akademickiego, którzy otrzymali nominacje. W gabinecie rektora Siedleckiego odbyło się 16 września 1919 roku pierwsze posiedzenie Senatu Akademickiego. Uczestniczyli w nim prócz rektora i sekretarza Uniwersytetu Jana Kaczkowskiego: prorektor J. Ziemacki, ks. B. Żongołłowicz, P. Wiśniewski i F. Ruszczyc ${ }^{56}$.

Jak słusznie zauważył Zbigniew Opacki, ten początkowo skromny liczebnie skład Senatu dowodził, że w końcu sierpnia nadal trwały pertraktacje w sprawie zatrudnienia i mianowania na stanowiska funkcyjne odpowiednich osób. Dotyczyło to m.in. profesorów: Mariana Zdziechowskiego przewidzianego na dziekana Wydziału Humanistycznego i Alfonsa Parczewskiego, który miał zostać dziekanem i organizatorem Wydziału Prawa i Nauk Społecznych ${ }^{57}$.

Do 11 października 1919 roku, czyli chwili otwarcia uczelni podczas uroczystej inauguracji roku akademickiego 1919/1920, zdołano uzupełnić obsadę dziekańską. I tak dziekanem Wydziału Humanistycznego ostatecznie został Józef Kallenbach, a dziekanem Wydziału Lekarskiego Emil Godlewski (junior). Nadal nieobsadzona była funkcja dziekana Wydziału Prawa i Nauk Społecznych oraz kilku prodziekanów. Przed 13 października 1919 roku J. Piłsudski powołał kolejne władze akademickie, w tym dziekana i prodziekana Wydziału Prawa i Nauk Społecznych: Alfonsa Parczewskiego i Władysława Zawadzkiego 58 .

Działalność L. Kolankowskiego przy organizacji wileńskiej uczelni zamknął dekret z 28 sierpnia 1919 roku o powołaniu USB oraz list Naczelnego Wodza z 30 sierpnia odwołujący go z funkcji organizatora Uniwersytetu. „Zapomniano” o nim także, zapraszając gości na uroczystość inauguracji USB w październiku 1919 roku ${ }^{59}$.

${ }^{56}$ LCVA, F. 175, ap. 1(I)A, b. 944, k. 168-169v, Protokół pierwszego posiedzenia Senatu Akademickiego Uniwersytetu Stefana Batorego w Wilnie w dniu 16 września 1919 r. w gabinecie rektora profesora Siedleckiego.

${ }^{57}$ Z. Opacki, Między uniwersalizmem a partykularyzmem. Myśl i działalność społeczno-polityczna Mariana Zdziechowskiego 1914-1938, Gdańsk 2006, s. 139. Marian Zdziechowski nie przyjął proponowanego stanowiska dziekańskiego, chociaż był wymieniony $\mathrm{w}$ dekrecie opublikowanym przez Jerzego Osmołowskiego z sierpnia 1919 r.; A. Wrzosek, Wskrzeszenie Uniwersytetu Wileńskiego, s. 30.

${ }^{58}$ LCVA, F. 175, ap. 1(I)A, b. 944, k. 162-163, Protokół Nr. 2 posiedzenia Senatu Akademickiego Uniwersytetu Stefana Batorego w Wilnie z dnia 13 października 1919 roku, w którym uczestniczyli: rektor M. Siedlecki, prorektor J. Ziemacki, dziekan Wydziału Teologicznego ks. B. Żongołłowicz, dziekan Wydziału Prawa i Nauk Społecznych A. Parczewski, dziekan Wydziału Matematyczno-Przyrodniczego P. Wiśniewski, dziekan Wydziału Lekarskiego E. Godlewski oraz Wiktor Staniewicz i Tadeusz Czeżowski. Nieobecni byli: dziekan Wydziału Humanistycznego J. Kallenbach i dziekan Wydziału Sztuk Pięknych F. Ruszczyc. Zob. też: H. Ilgiewicz, Uroczystości na Uniwersytecie Stefana Batorego w Wilnie, [w:] Na obrzeżach polityki: praca zbiorowa, cz. 9, pod red. M. Kosmana, Poznań 2013, s. 15-18.

${ }_{59}$ A. Wrzosek, Wskrzeszenie Uniwersytetu Wileńskiego, s. 29-30 - do Senatu USB powołano także: Wiktora E. Staniewicza jako prodziekana Wydziału Matematyczno-Przyrodniczego, ks. Kazimierza Zimmermanna jako prodziekana Wydziału Teologicznego i Stanisława Władyczkę jako prodziekana Wydziału Lekarskiego. Zob. też: L. Kolankowski, Zapiski pamiętnikarskie, s. 109,146 , z rozgoryczeniem wspomina o pominięciu jego roli we wskrzeszeniu wileńskiej 
Na nowo wskrzeszonym uniwersytecie już w październiku 1919 roku działało sześć wydziałów: humanistyczny, teologiczny, prawa i nauk społecznych, matematyczno-przyrodniczy, lekarski i sztuk pięknych ${ }^{60}$. Uczelnia funkcjonowała według postanowień „Statutu Tymczasowego Uniwersytetu Stefana Batorego w Wilnie” nadanego jej przez Naczelnego Wodza 11 października 1919 roku. Dokument utrwalał niezwykłą na polskim gruncie organizację szkoły wyższej. Był to przede wszystkim pierwszy nowy statut w niepodległej Polsce, zatwierdzony jeszcze w trakcie prac nad ustawą o szkołach akademickich, która ukazała się w lipcu 1920 roku. Nowatorskim posunięciem w nim było utworzenie w ramach uniwersytetu wydziału sztuk pięknych, podział tradycyjnego wydziału filozoficznego na dwa wydziały: humanistyczny i matematyczno-przyrodniczy, oraz połączenie nauk społecznych z wydziałem prawa (art. 8). Wprowadzał on też nieznaną uczelniom w Galicji, a występującą w uczelniach rosyjskich, instytucję „Zebrania ogólnego Profesorów” (art. 11-13). Zgodnie z art. 77 (s. 36) „Statutu Tymczasowego USB” ,[...] pierwszy skład grona nauczycielskiego i personelu urzędniczego i służbowego ustanowi zwierzchnia władza rządowa"61.

Kilkanaście dni przed uroczystą inauguracją do gazet przesłano odezwę następującej treści:

Komitet Obchodu Uroczystego Otwarcia Uniwersytetu Stefana Batorego w Wilnie zwraca się do obywateli miasta Wilna z uprzejmą prośbą by ci, którzy mają możność udzielenia (bezpłatnie lub za opłatą) dla przyjezdnych gości honorowych na czas uroczystości inauguracyjnych (9-15 Października) mieszkań lub pokoi, zechcieli niezwłocznie (do dnia 20 Września) porozumieć się z Komitetem Obchodu przez Kancelaryę Uniwersytecką (S-to Jańska 26 - godziny przyjęć w dnie powszednie od 9 do 3 po południu) ${ }^{62}$.

Uroczystość pierwszej uroczystej inauguracji była szczególnym momentem do zmierzenia się z legendą Uniwersytetu Wileńskiego. Organizatorzy zdecydowali się zaprosić na nią syna Adama Mickiewicza, Władysława, oraz innych krewnych dawnych wielkich absolwentów i twórców Uniwersytetu, np. wnuka księcia Adama Czartoryskiego, Adama Ludwika, Stanisława Mianowskiego, prawnuka Mikołaja Mianowskiego, profesora Uniwersytetu $\mathrm{z}$ XIX wieku i rektora Akademii Medyko-

uczelni; P. Żukowski, Uniwersytety we Lwowie, Krakowie i Wilnie na naukowej drodze Ludwika Kolankowskiego, s. 67-68.

${ }^{60}$ Planowano także utworzenie Wydziału Rolniczego, którego projekty pojawiały się już w pracach Komisji Organizacyjno-Rewindykacyjnej. Ostatecznie w 1924 r. udało się powołać Studium Rolnicze, które działało przy Wydziale Matematyczno-Przyrodniczym. Wydział Rolniczy USB został utworzony w kwietniu 1938 r., zob.: Dziennik Ustaw RP, 1938, nr 26, poz. 233 (z 9 kwietnia 1938 r.).

${ }^{61}$ Rozkaz Naczelnego Wodza Wojsk Polskich zawierający Statut tymczasowy Uniwersytetu Stefana Batorego w Wilnie, 11 X 1919 r., Wilno 1919, s. 7, art. 8 (Dziennik Urzędowy Ministerstwa Wyznań Religijnych i Oświecenia Publicznego RP, 1919, R. 2, nr 10-11, poz. 2 s. 304 317); D. Zamojska, Akademicy i urzędnicy, s. 100-101, 105-106, redakcję statutu wykonał Adam Wrzosek. Zob. też: Akt otwarcia Uniwersytetu Stefana Batorego w Wilnie, Dziennik Urzędowy Ministerstwa Wyznań Religijnych i Oświecenia Publicznego RP, 1919, R. 2, nr 10 11, poz. 1, s. 303-304.

${ }^{62}$ LCVA, F. 175, ap. 1(I)A, b. 7, k. 21, Odpis odezwy w sprawie udzielania przez mieszkańców mieszkań na okres uroczystości otwarcia uniwersytetu (tekst wysłany do gazet, m.in. redakcji „Naszego Kraju”, „Dziennika Wileńskiego”). 
Chirurgicznej, potomka Śniadeckich, Walerię Kulwieciową, córkę Andrzeja Towiańskiego i innych ${ }^{63}$.

W inauguracji uczestniczyli także trzej, zaproszeni przez organizatorów, delegaci Litewskiego Towarzystwa Naukowego w osobach prezesa Jonasa Basanavičiusa (Jana Basanowicza) oraz dwóch członków: ks. Józefa Tumasa i Jonasa Šepetysa. Ten ostatni wygłosił wówczas przemówienie po litewsku i polsku, w którym podkreślił, że „,...] Litwini, których on reprezentuje, zdecydowali się na wzięcie udziału w uroczystościach, gdyż wierzą, że uniwersytet ten będzie służył nie polityce i wynarodowianiu, lecz czystej wiedzy".

Opis uroczystości, która odbyła się w Wilnie w 10-12 października 1919 roku, znamy z licznych przekazów źródłowych. Tak ceremonię inauguracji w Auli Kolumnowej opisał pierwszy rektor USB:

[...] Na podjum, pod portretem Stefana Batorego, było ustawione krzesło dla Rektora, naprzeciw, na środku sali, krzesło dla Naczelnika Państwa. Po obu stronach krzesła rektorskiego zasiedli: z jednej strony Władysław Mickiewicz, z drugiej prorektor Józef Ziemacki. [...] Pomiędzy krzesłem Rektora, a krzesłem Naczelnika Państwa stał stolik, na którym złożono insygnja uniwersyteckie, na boku zaś drugi, na którym rozłożono pergamin, zawierający akt wskrzeszenia Uniwersytetu Wileńskiego. Były tylko dwa przemówienia: przemawiał Rektor i Naczelnik Państwa ${ }^{64}$.

Restytuowany po 87 latach w Wilnie Uniwersytet nawiązywał do dziedzictwa dawnej, sławnej Akademii Wileńskiej, z której w 1919 roku pozostały jedynie mury utożsamiane w mieście ze szkołą wyższą, w której uczył się Adam Mickiewicz, oraz garść symboli w tradycji ustnej przekazywanej z pokolenia na pokolenie ${ }^{65}$. Odtworzenie ciągłości Almae Matris Vilnensis wymagało uporu i zaangażowania wielu osób. Pomysłodawcy i założyciele USB musieli zmierzyć się z trudnościami finansowymi w mieście ogołoconym przez kolejnych okupantów, lokalowymi, bo wiele pomieszczeń nawet $w$ gmachach przy ul. Uniwersyteckiej długo jeszcze zajmowały instytucje miejskie i państwowe (żeby wymienić tylko Archiwum Państwowe w Wilnie), oraz personalnymi.

Najtrudniej było jednak sprostać oczekiwaniom Wilnian. Legenda utrwalona w pamięci miasta powodowała, że każdy mieszkaniec Wilna nosił w sercu „swój” Uniwersy-

${ }^{63}$ Uroczyste otwarcie Uniwersytetu, Nasz Kraj 1919 nr 145 (z 12 października), s. 9; S. Mianowski, Świat, który odszedt: wspomnienia Wilnianina 1895-1945, wyboru dokonali oraz przygot. do dr. M. z Mianowskich Parczewska, K. M. Mianowski, Warszawa 1995, s. 122-123. W. Kulwieciowa w dniu pierwszej inauguracji podarowała uczelni portret Andrzeja Towiańskiego pędzla Walentego Wańkowicza.

${ }^{64}$ M. Siedlecki, Wspomnienia z pierwszych dwu lat organizacji Uniwersytetu Wileńskiego, s. 75-76; F. Ruszczyc, Dziennik, cz. 2: W Wilnie, s. 43-51, szczegółowo opisał pierwszą inaugurację roku akademickiego 1919/20. Zachowała się dokumentacja z otwarcia Wszechnicy w Wilnie obejmująca m.in. mowy wygłoszone w trakcie uroczystości otwarcia Uniwersytetu oraz telegramy i depesze z życzeniami wysłanymi z tej okazji (oryginały i odpisy) - zob.: LCVA, F. 175, ap. 1(I)A, b. 19-22. Stanowisko inteligencji litewskiej wobec otwarcia Uniwersytetu w Wilnie przedstawiono w artykule Stanowisko społeczeństwa litewskiego wobec wskrzeszenia Uniwersytetu Wileńskiego w r. 1919 zamieszczonym w czasopiśmie Przegląd Wileński 1929 nr 18-19 (z 27 października), s. 2-7.

${ }^{65}$ Zob.: W. Krupowies, Rok 1919: pamięć Wilna - pamięć w Wilnie, Acta Baltico-Slavica 2018 vol. 42, s. 81-98, pisze o pamięci kulturowej, ale też o pamięci indywidualnej i rodzinnej, dzięki której przeszłość wileńskiego uniwersytetu przetrwała i została przeniesiona na kolejne pokolenia. 
tet, bez względu na to, czy miał jakieś związki rodzinne lub zawodowe z Almae Matris Vilnensis i jej wychowankami. Sugestywnie opisał to Antoni Gołubiew, podkreślając, że każdy Wilnianin czuł się niejako wyróżniony przez to, że miasto ma Uniwersytet:

[...] Nie bardzo pamiętano batoriańską akademię jezuitów i rektorat Piotra Skargi — to była tradycja podręcznikowa, archiwalna, przysypana pyłem bibliotecznym, tradycja uczonych i szperaczy. Ale uniwersytet filomatów-filaretów [...], Adama Mickiewicza i trzeciej części „Dziadów [...], Śniadeckich czy Lelewela [...], obserwatorium astronomiczne Poczobutta, czy ogród botaniczny Jundziłła [...] — otóż ta tradycja Uniwersytetu była ciągle jeszcze żywa. Bóg wie, jakimi drogami Poczobutt i Jundziłł przesiąkali do powszechnej świadomości, ale jakoś przesiąkali [...]. Owo powszechne uznawanie przez wilnian Uniwersytetu za swój, za o s o b i ś c i e własny trudno wytłumaczyć ludziom nie tutejszym. A była to nazwyczajniejsza prawda. [...] natomiast uniwersytet nie był obcy dla stróża czy przekupki kaziukowej, chociaż przecież żadne z nich nic nie miało $z$ uniwersytetem do czynienia, nie bardzo wiedziało, czym on jest $[\ldots]^{66}$.

Owa legenda, konieczność spełnienia oczekiwań tysięcy osób, powodowała nieporozumienia i spory, które rozsądził Naczelny Wódz Józef Piłsudski, dekretując Uniwersytet Stefana Batorego. To był jego Uniwersytet, a odpowiedzialność kazała mu wspierać wileńską uczelnię także w sposób niemal symboliczny. Znamy wiele przykładów tego wsparcia, np. przekazanie pensji Naczelnika Państwa na rzecz uczelni, donacja na rzecz remontu budynków dla Wydziału Matematyczno-Przyrodniczego (przy rogu ul. Objazdowej i Zakretowej) czy nagranie płyty, dochód ze sprzedaży której także trafiał do kasy USB. Uczelnia odgrywała szczególną rolę w życiu Wilna. O roli tej pisał we wspomnieniach jej wychowanek i jeden z profesorów — ks. Walerian Meysztowicz:

Nikt dziś nie wie czym były dla nas mury uniwersyteckie, dawne kolegium jezuickie przy kościele św. Jana. Jakie uczucia budził Uniwersytet Śniadeckich, Mickiewicza i Lelewela, uniwersytet mego pradziada [...] Miłe miasto widzę w snach — w ciasnej gdzieś ulicy - stoi stary drogi gmach - mury mej wszechnicy. Właściwym centrum Wilna był Uniwersytet Stefana Batorego. Ton miastu nadawała młodziez ${ }^{67}$.

\section{LITERATURA}

Źródła

Lietuvos Centrinis Valstybes Archyvas w Wilnie (dalej: LCVA), F. 175, ap. 1(I)A, b. 1 (Listy profesorów i instytucji oświatowych); F. 175, ap. 1(I)A, b. 4 (Telegramy); F. 175, ap. 1(I)A, b. 5 (Zaproszenia na zebrania); F. 175, ap. 1(I)A, b. 7 (Listy do redakcji); F. 175, ap. 1(I)A, b. 9 (Listy w sprawie zapisów); F. 175, ap. 1(I)A, b. 12a (Protokoły Komitetu Wykonawczego Odbudowy Uniwersytetu Wileńskiego, oryginały); F. 175, ap. 1(I)A, b. 13 (Protokoły Komisji Organizacyjno-Rewindykacyjnej, oryginały i odpowiedzi); F. 175, ap. 1(I)A, b. 14 (Protokoły poszczególnych komisji); F. 175, ap. 1(I)A, b. 16 (Różne sprawy Komitetu Wykonawczego); F. 175, ap. 1(I)A, b. 18 (Fotografie i życiorysy członków Komitetu Wykonawczego); F. 175, ap. 1(I)A, b. 19-22 (Mowy wygłoszone w czasie uroczystości otwarcia Uniwersytetu 11 X [19]19); F. 175, ap. 1(I)A, b. 48 (Sprawy budżetowe 1920/21); F. 175, ap. 1(I)A, b. 944 (Protokoły posiedzeń Senatu 1919/20); F. 175, ap. 2(VI)B, b. 2 (Rękopisy Wydziału Prawa i Nauk Społecznych USB 1929/30).

\footnotetext{
${ }^{66}$ A. Gołubiew, Unoszeni historia, Kraków 1971, s. 283-284.

${ }^{67}$ W. Meysztowicz, Gawędy o czasach i ludziach, Londyn 1993, s. 215, 228.
} 
Opracowania

Akt otwarcia Uniwersytetu Stefana Batorego w Wilnie, Dziennik Urzędowy Ministerstwa Wyznań Religijnych i Oświecenia Publicznego RP, 1919, R. 2, nr 10-11, poz. 1.

Dziennik Ustaw RP, 1938, nr 26, poz. 233 (z 9 kwietnia 1938).

Dziewulski W., Prawda o wskrzeszeniu Wileńskiej Wszechnicy w 1919 roku, [w:] Z dziejów Almae Matris Vilnensis: ksiegga pamiatkowa ku czci 400-lecia założenia i 75-lecia wskrzeszenia Uniwersytetu Wileńskiego, red. L. Piechnik, K. Puchowski, Kraków 1996.

Gierowska-Kałłaur J., Między polityka a nauka. Ludwik Kolankowski w pierwszym pótroczu 1919 roku, [w:] Ludwik Kolankowski: dzieło i życie: indywidualny przypadek historiograficzny, red. P. Oliński, W. Piasek, Torun 2017.

Gierowska-Kałłaur J., Zarząd Cywilny Ziem Wschodnich: (19 lutego 1919-9 września 1920), Warszawa 2003.

Gołubiew A., Unoszeni historia, Kraków 1971.

Ilgiewicz H., Relacje polsko-litewskie w przededniu odzyskania niepodległości w świetle dzienników $i$ wspomnień działaczy wileńskich, „Rocznik Stowarzyszenia Naukowców Polaków Litwy" 2019 , t. 19.

Ilgiewicz H., Societates Academicae Vilnenses: Towarzystwo Przyjaciót Nauk w Wilnie (19071939) i jego poprzednicy, Warszawa 2008.

Ilgiewicz H., Uroczystości na Uniwersytecie Stefana Batorego w Wilnie, [w:] Na obrzeżach polityki: praca zbiorowa, cz. 9, pod red. M. Kosmana, Poznań 2013.

Ilgiewicz H., Wileńskie towarzystwa naukowe $w$ latach pierwszej wojny światowej, „Rocznik Stowarzyszenia Naukowców Polaków Litwy" 2015, t. 15.

Jegelevičius Sigitas, Pierwsze próby wskrzeszenia Uniwersytetu Wileńskiego i powstanie Uniwersytetu Stefana Batorego, [w:] Z dziejów Almae Matris Vilnensis: księga pamiątkowa ku czci 400-lecia założenia i 75-lecia wskrzeszenia Uniwersytetu Wileńskiego, red. L. Piechnik, K. Puchowski, Kraków 1996.

Jurkowski R., U źródet Uniwersytetu Stefana Batorego - początki Wydziatu Teologicznego (1918-1920), „Echa Przeszłości” 2017, t. 18.

Kolankowski L., Zapiski pamiętnikarskie, do druku przygotowała, wstępem i przypisami opatrzyła S. Grochowina, Torun 2012.

Konferencje Rektorów Szkót Akademickich w Polsce w latach 1919-1931: protokóty narad, uchwaty i memoriaty, ze wstępem S. Estreichera, red. L. Zembrzuski, Warszawa 1932.

Kozłowska-Studnicka J., Likwidacja Uniwersytetu Wileńskiego w świetle korespondencji urzędowej, [w:] Księga pamiątkowa, ku uczczeniu CCCL rocznicy zalożenia i X wskrzeszenia Uniwersytetu Wileńskiego, t. 1: Z dziejów dawnego Uniwersytetu, Wilno 1929.

Krupowies W., Rok 1919: pamięć Wilna - pamięć w Wilnie, „Acta Baltico-Slavica” 2018, vol. 42.

Meysztowicz W., Gawędy o czasach i ludziach, Londyn 1993.

Mianowski S., Świat, który odszedt: wspomnienia Wilnianina 1895-1945, wyboru dokonali oraz przygot. do dr. M. z Mianowskich Parczewska, K. M. Mianowski, Warszawa 1995.

Opacki Z., Między uniwersalizmem a partykularyzmem. Myśl i działalność społeczno-polityczna Mariana Zdziechowskiego 1914-1938, Gdańsk 2006.

Opacki Z., Reaktywowanie czy powstanie? Dyskusje wokót utworzenia Uniwersytetu Stefana Batorego w Wilnie w latach 1918-1919, „Kwartalnik Historyczny” 1998, R. 105, nr 3.

Opacki Z., Środowisko naukowe USB w Wilnie wobec polsko-litewskiego sporu terytorialnego o Wileńszczyznę w latach 1919-1922, [w:] Polacy i sąsiedzi - dysonanse i przenikanie kultur, cz. 2: zbiór studiów, red. R. Wapiński, Gdańsk 2001.

Ruszczyc, Dziennik, cz. 2: W Wilnie 1919-1932, wybór, układ, opracowanie, wstęp i posłowie E. Ruszczyc, Warszawa 1996.

Schiller J., Universitas rossica: koncepcja rosyjskiego uniwersytetu 1863-1917, Warszawa 2008.

Siedlecki M., Wspomnienia z pierwszych dwu lat organizacji Uniwersytetu Wileńskiego, [w:] Księga Pamiatkowa ku uczczeniu CCCL rocznicy założenia i X wskrzeszenia Uniwersytetu Wileńskiego, t. 2: Dziesięciolecie 1919-1929, Wilno 1929. 
Srebrakowski A., Litwa i Litwini na Uniwersytecie Stefana Batorego, [w:] Stosunki polsko-litewskie wczoraj i dziś: historia, kultura, polityka, red. W. K. Roman i J. Marszałek-Kawa, Torun 2009.

Srebrakowski A., Uniwersytet Stefana Batorego w Wilnie 1919-1939, [w:] Wrocław na litewskie millenium. Materiały z uroczystej konferencji z okazji 1000-lecia udokumentowania nazwy Litwa, pod red. A. Srebrakowskiego i G. Straucholda, Wrocław 2010.

Statut tymczasowy Uniwersytetu Stefana Batorego w Wilnie, 11 X 1919 r., Wilno 1919 (Dziennik Urzędowy Ministerstwa Wyznań Religijnych i Oświecenia Publicznego RP, 1919, R. 2, nr 10-11, poz. 2).

Stepono Batoro universitetas: perimti ir isigyti turtai (1919-1939), [w:] Alma Mater Vilnensis: Vilniaus universiteto turtai istorijos skersvejuose (XVI-XXI amžiai), [redaktorių kolegija], Vilnius 2016.

Sukiennicki W, Legenda i rzeczywistość: wspomnienia i uwagi o dwudziestu latach Uniwersytetu Stefana Batorego w Wilnie, Paryż 1967.

Uroczyste otwarcie Uniwersytetu, „Nasz Kraj” 1919, nr 145 (z 12 października).

Władyczko S., Pierwszy okres prac organizacyjnych nad odbudowa Uniwersytetu Wileńskiego (13.XII.1918-11.X.1919). Sprawozdanie Komitetu Wykonawczego Odbudowy Uniwersytetu Wileńskiego, [w:] Księga Pamiatkowa ku uczczeniu CCCL rocznicy założenia i X wskrzeszenia Uniwersytetu Wileńskiego, t. 2: Dziesięciolecie 1919-1929, Wilno 1929.

Wołkanowski W., Michat Węstawski: biografia prezydenta Wilna w latach 1905-1916, Opole 2015.

Wrzosek A., Wskrzeszenie Uniwersytetu Wileńskiego w roku 1919, [w:] Ksiega pamiatkowa, ku uczczeniu CCCL rocznicy założenia i X wskrzeszenia Uniwersytetu Wileńskiego, t. 2: Dziesięciolecie 1919-1929.

Zamojska D., „,Ta ludność życzy mieć uniwersytet... - walka o utworzenie Uniwersytetu Stefana Batorego w Wilnie, „Kwartalnik Historii Nauki i Techniki” 2006, t. 51, z. 2.

Zamojska D., Akademicy i urzędnicy: kształtowanie ustroju państwowych szkót wyższych w Polsce 1915-1920, Warszawa 2009.

Zamojska D., Konferencje rektorów szkół akademickich $w$ Polsce $w$ okresie międzywojennym: reprezentacja środowiska akademickiego wobec zmian ustawodawstwa, „Rozprawy z Dziejów Oświaty" 2004, t. 43.

Ziemacki J., O wznowieniu Uniwersytetu $w$ Wilnie, cz. 1-2, „Dziennik Wileński” 1918, nr 270 (20 listopada), s. 2-3; nr 272, s. 2 (z 22 listopada).

Żukowski P., Uniwersytety we Lwowie, Krakowie $i$ Wilnie na naukowej drodze Ludwika Kolankowskiego. Życie naukowe Ludwika Kolankowskiego do 1939 roku, [w:] Ludwik Kolankowski: dzieło i życie: indywidualny przypadek historiograficzny, red. P. Oliński, W. Piasek, Torun 2017.

\section{ALMA MATER VILNENSISI: THE RECONSTITUTION OF STEPHEN BATHORY UNIVERSITY IN VILNIUS}

The article discusses the early $20^{\text {th }}$-century attempts of the Polish intellectual elites to re-establish in Vilnius the institution of higher education which had been closed by a tsar's ukase in 1832. It focuses on the efforts undertaken in 1915-1919, which led to the foundation of Stephen Bathory University (Universitas Batoreana Vilnensisi) by a decree of Chief of State Józef Piłsudki's on 28 August 1919.

KEY WORDS: Stephen Bathory University, reconstitution of the Academy of Vilnius, first inauguration of the academic year, education in the $20^{\text {th }}$-century Vilnius, Revindication and Organization Committee, Chief of State decree SŁOWA KLUCZOWE: Uniwersytet Stefana Batorego, wskrzeszenie Wszechnicy Wileńskiej, pierwsza inauguracja roku akademickiego, nauka w Wilnie w XX wieku, Komisja Rewindykacyjno-Organizacyjna, dekret Naczelnego Wodza 